\title{
Global Geopolitical Developments and Opportunities for Lithuania's Foreign Policy
}

\begin{abstract}
The changes in geostrategy of the United States have become clear after the events of September 11. These changes have encouraged the reformation and adaptation process of the geopolitical codes of the other main geopolitical actors. Germany, France, the United Kingdom, Russia and China are facing the necessity either to adapt to the transformed US geostrategy or to project and implement alternative geopolitical combinations striving for its neutralisation. The change of the geopolitical codes of the main geopolitical actors (including various alternatives variants) would_shape the main tendencies of global geopolitical development at the beginning of the 21st century. It is necessary to evaluate the action scenarios of the main geopolitical actors_in order to identify the opportunities of Lithuania's geopolitical code and also Lithuania's foreign policy transformation in the global geopolitical environment since the possibilities of Lithuania's foreign policy directly depend on the changes of the global geopolitical situation. The analysis of global geopolitical development and the identification of opportunities of Lithuania's foreign policy are based both on static and dynamic approaches. This study identifies the interests of the US, Russia, major powers of the European Union (EU) and China in the global geopolitical environment. Such identification sets the conditions for Lithuania's possible location in the geostrategic plans of the great powers and that is the static part of the analysis. The dynamic part of the analysis relies on the model of the strategic choice and presents the main geostrategic alternatives of the most important geopolitical actors. They depend on the changes of interaction among the geopolitical subjects. The models of this interaction allow identifying possible global geopolitical scenarios and evaluating Lithuania's eventual geopolitical role in the changing geopolitical space.
\end{abstract}

\section{Introduction}

Lithuania's geopolitical situation determines the dependence of its international environment on the interrelations among Russia, the US, and the major powers the EU. Lithuania's possibilities to achieve own geopolitical vision and implement specific functions in international relations mainly depend on its place and level of attention to it in the geostrategic plans of the major geopolitical actors mentioned above.

\footnotetext{
Dr. Egidijus Motieka - is an associate professor of the Institute of Political Science of the University of Vilnius (IIRPS of the UV);

Dr. Nortautas Statkus is an aassociate professor of the IIRPS of the UV;

Jonas Daniliauskas is PhD candidate of the IIRPS of the UV. Address: Vokiečiu 10, LT-01130

Vilnius, tel. +370-5-2514130.
} 
The interrelations among the US, Europe, Russia and China as it historically has arisen will determine the transformation opportunities of all the international system and the character of the geopolitical structure in the 21st century. The possibilities of Russia to get stronger or the US possibilities to dominate the world depends on the situation in Europe, which is one of the main clash zones of the geopolitical interests (who will be the dominating power in Europe), Europe's position (whose side Europe will support) and also on the global politics of China.

France, Germany and the United Kingdom are regional powers in Europe. They lost the status of independent geopolitical actors during the Cold War. They face the dilemma of choice now: either to permanently become geopolitical allies of the US or by mobilising their own capabilities through common European defence and security institutions to create a federal EU and convert it into a global geopolitical actor.

\section{The Interests of the Global Geopolitical Actors in Eurasia}

The global geopolitical development is an interrelation determined by the strategic choices (and implementation of strategies) of geopolitical subjects. The consequences of this development are the variations of the subjects' power spread in the space. The analysis of geopolitical processes is based on the approach of strategic choice in the discipline of international relations. It is one of the approaches of the paradigm of rational choice. The proponents of the approach of the strategic choice suggest that actors (geopolitical subjects in this case) have goals (interests), prioritise them and seek to implement them by the best means in their own consideration. The actors create strategies for achieving their goals. The implementation of the actor's strategies create the interaction with other subjects and strategic choices of these subjects (the actor's environment) determining the goal achievement of the actor in the international system ${ }^{1}$.

While researching the interests of the geopolitical actor, objective and subjective levels must be distinguished. It is possible to identify the optimal conditions and circumstances of existence (so-called objective interests) of state (or other subject) and to create the strategies adequate to reality, which would form or secure these conditions and prevent the emergency of new threats. The comprehension of state (and other actors) interests depend on the internal structure of political and economic powers and also on the presumption and definition of the interests of other subject and the threats arising from them (so-called subjective interests). Of course, this does not mean that the interests of geopolitical subjects (including geopolitical codes) are only totally subjective social constructs. The interests of the actor are the inter-subjective social construct, which forms and is formed through the interaction among political coalitions in the state (or an other international actor) and through the interaction among states (or other actors). The particular formula of interest of a

\footnotetext{
${ }^{1}$ Lake D.A., Powell R., "International Relations: A Strategic-Choice”, in Lake D.A., Powell R., eds., Strategic Choice and International Relations, New Jersey: Princeton University Press, 1999, p. 3-38.
} 
particular actor is determined by the power relations of internal groups and their coalitions and the bargaining process of these coalitions, by the international environment and by the state's situation in the structure of the global geopolitical system².

The interests of geopolitical subjects can be vital, primary and secondary ones depending on their importance. Political actors embed this division through the programs and strategies of the parties or governments. The interests can be local, regional and global ones depending on the extent of their spread through space. The interests of geopolitical subjects are also divided into common (permanent), (geo) strategic (fairly stable with insignificant changes), long-term and short-term ones depending to their extension through the time ${ }^{3}$.

\subsection{The Interests of the United States}

The United States is a super-power, the hegemon of the international system ${ }^{4}$. The US dominates in the maritime geostrategical zone, space and cyber-sphere. The US economy is one of the most powerful in the core zone.

The fundamental geostrategic interest of the US is politically divided Eura$\mathrm{sia}^{5}$. The control of Eurasian coasts (discontinental geostrategic zone) is very important for the US. The continental powers can not (because of lack of access) challenge the US global domination in the oceans (and also could not threaten the security of the US mainland territory as well) until the US controls the discontinental geostrategic zone (in combination with domination in the air and space) of Eurasia ${ }^{6}$.

Of course, those are only the minimal geostrategic interests of the US. The current international order depends mainly on the US. The global stability of current international system and the preservation of its unipolar structure is the long-term interest of the US.

Thus, the geopolitical pluralism in Eurasia is not enough to guarantee the global stability and, therefore, the US strives for the final establishment of its hegemonic status.

\footnotetext{
${ }^{2}$ Statkus N., Motieka E., Laurinavičius Č., Geopolitiniai kodai: tyrimo metodologija., Vilnius: Vilniaus universiteto leidykla, 2003, p. 65-66.

${ }^{3}$ Ibidem, p. $68-69$.

${ }^{4}$ Ikenberry J. G., ed., America Unrivaled: The Future of the Balance of Power, Ithaca: Cornell University Press, 2002; Ferguson N., Colossus: The Price of America's Empire, New York: The Penguin Press, 2004.

${ }^{5}$ Brzezinski Z. Velikaja shachmatnaja doska, Moscow: Mezhdunarodnye otnoshenya, 1999, p. 5254, also see Brzezinski Z., The Grand Chessboard: American Primacy and Its Geostrategic Imperatives, Basic Books, 1997.

${ }^{6}$ The majority of the USA military bases are deployed exactly in the discontinental geostrategic zone (17,000 US troops are dislocated in Europe, 101,000 in East Asia and the Pacific, 30,000 in North Africa and the Middle East (prior to Iraq War), 5,400 in the other countries of North and South America, 160 in the counties of former Soviet Union. The US are entered into collective (multilateral) treaties on defence not only with the other 18 countries of NATO, but also New Zealand, Australia, Philippines, Japan and South Korea and the less bounding agreements of the co-operation in defence with most countries of Latin America, see Paulauskas K., JAV gynybos pramones raida ir poveikis santykiams su Europa, Vilnius: LR Krašto apsaugos ministerija, 2004, p. 47.
} 


\subsection{The Interests of Russia}

Russia lost the status of super-power and became one of the regional powers after the Cold War. Russia's dive into the geoeconomic periphery is a real possibility. However, Russia still controls one of the three geostrategic zones of world - the continental zone of Eurasia, i.e. the heartland. The interests of continental Russia are diametrically opposite to the interests of the maritime powers. Being the continental power, Russia seeks to control all the resources and shores of Eurasia's continent and also aims to create the sea, air and space forces matching the power of maritime powers and bear the conventional efficiency of the land forces.

The main short-term goal of Russia is the necessity to hold in the semi-periphery and to avoid diving into the periphery. The long-term economic goal is to become part of the geoeconomic core. Russia tries to mobilize human, natural and technological resources in order to enhance productivity and production quality. Therefore, the Russian ruling elite has interest in the political, administrative and economic centralisation of Russia, which would be helpful for the successful policy of "modernisation" ("transition").

The direct or indirect control of Eurasian shores would be one of the main Russia's geostrategical interests, since this would fundamentally guarantee Russia's security. To achieve this, Russia should drive out the US from Eurasia. Although, understanding the difficulty of this aim (even in a long-term perspective) Russia should create such combinations of international politics, which would eventually help to reduce the influence of the US in Europe and the remaining discontinental zone. Russia expects to retain the super-power status by these actions. In the midterm, Russia seeks to restore influence on the former Soviet Union countries and also on the Baltic States. The reintegration of CIS countries is very important to Russia politically, military and economically, but the main goals are to stop the spread of influence of the US in the former Soviet Union territory (Moldova, Ukraine and South Caucasus) and enhance the effectiveness of use of its resources for geopolitical goals in the short-term.

\subsection{The Interests of the Main Powers of the European Union}

Almost all member states of the EU (except the United Kingdom and Ireland) belong to the discontinental geostrategic zone. All of them are the part of the world geoeconomic core zone.

The EU could not be considered as sole geopolitical subject, which has united interests and common geopolitical strategy. The common economic, security and foreign policy interests of the EU are the projection of the coinciding geopolitical interests of its member states. In other words, the interests and perception of the threats of the EU derives from the interests and perceptions of threats of the member states. In fact, the Common Foreign and Security Policy (CFSP) is determined by the most powerful member states, especially Germany. The agreement on a particular issue of the member states determines the implementation of the CFSP. The common policy is paralysed in the spheres where the agreement is absent. 
The economic interests of the EU are best articulated of all the interests, since the EU primarily an economic structure. West European continental states are interested in maintaining their welfare and status, i.e. they are interested to maintain the unequal swap with semiperiphery and periphery. The stable supply of natural resources, the protection of technologies, trade roads and supply of resources, the ruining of the industry of competitors from the semiperiphery and the free access to the markets of the semiperiphery and periphery could guarantee the current welfare and status of Europe.

The geostrategic and long-term interests of the most powerful members of the EU differ strongly. The main part of the territory of the United Kingdom is on the British Isles. This determines the maritime (talasocratic) civilisation and power of the UK. The base of the United Kingdom's security is ruling over the oceans by strong navy and the control of the main sea-routes and straits. On the other hand, the political elite of the Great Britain realise, that security of their state could be guaranteed by heading off the way for the dominance of one or another continental state of Europe. The specifically British "perfect isolation" and the balancing policy were the consequence of these presumptions ${ }^{7}$.

The UK tries to balance continental European powers with the power of US, guided by the reason that their basic regional interests and position on the EU are very similar. Neither the US, nor the UK wishes the EU to transform into a consolidated geopolitical subject. The US does not wish that, because it menaces the loss of its influence in Europe and the UK fears partial loss of the sovereignty and subordination of the UK to the continental core consisting of France and Germany. The UK may support the EU model, which includes some features of true confederation such as the a President of the EU Council or a foreign minister of the EU. Though, the fully integrated security, defense, tax and social policies are contrary to the general interests of the UK. Such level of integration would infringe UK sovereignty. Also such policies could be disadvantageous to the UK's economy and social system (both of them are rather different from the continental European states) as well. Besides, this could split the strategic alliance with the US. The fairly decentralised EU with rather limited competence of central institutions is preferable to the $\mathrm{UK}^{8}$.

Germany is a typical state of the discontinental zone (rimland) and it represents the advantages and vulnerabilities of it. The characteristics of the discontinental zone implies the active state and society and the certain indetermination of the internal and foreign policy at the same time. This indetermination is caused by the opportunities of the geopolitical orientation towards both the maritime or heartland powers and making the alliances with the states of one or another geostrategic zone.

The main elements of the current geopolitical code of Germany incite its "dissolving" in supranational structures, first of all the EU (the geopolitical internationalism). But there is the tendency of implementation of Germany's national interests through the institutions of the EU instead of "dissolving" in it. The main interests of Germany are:

${ }^{7}$ Laurinavičius Č., Motieka E., Statkus N., Baltijos valstybiu geopolitikos bruožai. XX amžius, Vilnius: Lietuvos Istorijos institutas, 2005, p. 230-231.

${ }^{8}$ Ibidem. 
- preservation of the common transatlantic institutions

- complete integration of the former East Germany ern Europe ${ }^{9}$

- deepening the integration of the EU and enlarging it by incorporating East-

Germany is the largest and one of the richest countries in the EU and, therefore, is interested in the EU's federalisation, since this provides the opportunities to influence the other member states through the central institutions of the Union ${ }^{10}$. Germany is likely to support the Europeanisation of Eastern Europe and Turkey and their eventual integration into the EU after the establishment of its influence on the central federal structures of the Union.

The context of the national interests always shaped the attitude of France towards the CFSP. According to French perception, the EU should balance the power of the US and limit the power of the potential rivals of France (especially that of Germany) in Europe. France supports the federalisation of the EU and advocate for the enhancement of the role of its largest members. France is inclined to use the EU further as a tool for the enhancement and guaranteeing of France's prestige. France seeks to establish such a structure of the enlarged EU, that would allow finding and implementing the common position, but the individual countries would preserve the priority of national interests in the spheres of vital importance to them at the same time ${ }^{11}$. The EU designed by France is more confederation than federation, though France might also support and federal EU structure, in case this would guarantee equal domination by France and Germany in the European subcontinent.

The interests of the continental European states like France and Germany and their allies (Belgium, Luxembourg, and Austria) are rather similar and coincide in many spheres. These countries could be called EU "continental core". This "continental core" is likely to have the common long-term interests towards the US, Russia and China.

Europe and the US are closely bounded together by economic, common defense and other social ties. They set up one geopolitical supraregion ${ }^{12}$. The economical interdependence of the US and Europe is mutual ${ }^{13}$. The EU strongly depends on the "hard security" provided by the USA. Any impetuous cessation of the transatlantic relations would affect the EU security ant the welfare negatively. The radical shift of the EU from the transatlantic relations towards the counter-alliances with Russia or China in order to block the power of the United States is disadvantageous for the continental Europe likely ${ }^{14}$.

\footnotetext{
${ }^{9}$ Ibidem.

${ }^{10}$ Heffernan M., The Meaning of Europe: Geography and Geopolitics, London: Arnold, 1998, p. 129.

${ }^{11}$ Laurinavičius Č., Motieka E., Statkus N., (note 7) p. 274.

${ }^{12}$ Statkus N., Motieka E., Globalios ir Baltijos valstybių geopolitinès situacijos pokyčiai, Lietuvos metine strategine apžvalga 2003, Vilnius: Lietuvos Karo Akademija, 2004, p. 9-53.

${ }^{13}$ The trade with Europe compose the 25 per cent of the US foreign trade (i.e. about 400 billion USD), 50 per cent of the US investments are in Europe (about 800 billion USD), 75 per cent of foreign investments to the US are from Europe (about 1 trillion USD) in 2003. 58 per cent assets of the US corporations (with value of 3 trillion USD) are in Europe and European assets in the US have a value of 3.3 trillion USD. There are about 4 million Europeans working for the US companies and about 4,5 million Americans working for the European corporations, see Sobel C.M., "The United States and Europe: Regulatory Cooperation and Conversion”, International Law and Practice Association of the New York State Bar Association, Amsterdam, October 26, 2003, http:// www. Usemb.nl/102403.htm, 14072004

${ }^{14}$ Hunter R. E., Europe's Leverage, The Washington Quarterly, 27, 1, 2003, p. 91-110.
} 
But this does not mean that "continental core" of the EU is not interested in the development of close relations with Russia or China. The EU needs Russia as:

- the supplier of energy resources ${ }^{15}$

East Asia

- the space with the important transport corridors into East, South and South-

- the partner of common projected structure of the European defence ${ }^{16}$

Generally, the continental core states of the EU consider Russia as a geopolitical counterweight to the dominance of the US in the short-term and mid-term perspective and as the strategic partner in the case of Russia's Europeanization to the sufficient level in the long-term. ${ }^{17}$

China is considered by the European continental countries only as a tactic partner to limit the power of the US. The long-term interests of the EU continental core and China are very different and China is the geostrategic and geoeconomic rival of the EU.

\subsection{The Interests of China}

The main part of China's territory belongs to the discontinental geostrategic zone (rimland), so it has the similar interests like the continental European states. These interests are the avoiding the domination of the heartland or maritime powers and the possibility of making alliances with one or another. The states, which are in discontinental zone must have fairly powerful sea, air and land forces ant the alternative supply sources of various resources ${ }^{18}$.

China, like Russia, belongs to the world's geoeconomic semiperiphery, but the difference from Russia is that China's economy is growing and modernising rapidly ${ }^{19}$. If China's economy would keep the current growth rates (7-8 per cent annually), it will catch up with Europe and North America by the size of GDP by $2030^{20}$. However, China has rather modest own oil and gas reserves. China's demand for the oil should grow by 91 per cent to the 8.8 million barrels per day (almost the same amount of the current export by Russia or Saudi Arabia) during 2000-2020.

\footnotetext{
${ }_{15}$ The EU and Russia are closely connected in geoenergetic sphere. The member states of EU import about one-fifth of consumed oil and about one-third of consumed gas from Russia. According to forecasts, the EU will import 70 per cent of energy resources in 2030 . The main part of them (especially oil and gas) will come from Russia. The 98 per cent of gas export and 81 per cent of oil export of Russia is to the EU, see Jaffe A. M., Manning R.A., Russia, Energy and the West, Survival, 43, 2, 2001, p. 133-152.

${ }^{16}$ Laurinavičius, Č., Motieka E., Statkus N., (note 7) p. 335.

${ }^{17}$ Emerson M., "The EU-Russia-US Triangle", CEPS Policy Brief 52, Centre for European Policy Studies, June 2004, http://www.ceps.be, 29102004.

${ }^{18}$ Statkus N., Motieka E., Laurinavičius Č., (note 2) p. 69.

${ }^{19}$ If the GDP growth of China would remain at the rate of 7-8 per cent per year, it should surpass the one of the EU and almost catch up with that of the US. See: The National Intelligence Council, Global Trends 2015: A Dialogue About the Future With Nongovernment Experts, http://www.cia.gov/ nic/NIC globaltrend2015.html, 0510 2004; Sutter R., Why Does China Matter?, The Washington Quarterly, 27, 1, p. 75-89.

${ }^{20}$ Russett B., Stam A., Russia, NATO, and the Future of U.S.-Chinese Relations, http://www.fas.org/ man/nato/ceern/nato-final_vs.htm
} 
The gas demand should increase by 631 per cent, or 9.5 trillion square foot in $2020^{21}$.

China, like a few other great powers (Russia, France and Germany) is hostile to the dominance of the US and to the unipolar structure of the world. China supports the vision of multipolar world. China aims to be an equal partner of the US and play an important role in solving the global problems in the future ${ }^{22}$. However, Beijing realises the current differences of power and influence between China and the US and co-operates with the US. China needs the favour of the US for securing peaceful external environment, foreign investments, export of energy resources from the Gulf through sea-routes controlled by the US and the obtaining the modern technologies, i.e. everything what is necessary to the development of economy. The permanent economic growth is the main precondition for the social and political stability in China and the main condition to expand its influence. Therefore, China aims to strengthen its relative power and to build up the secure external environment, which would be favourable for the economical development, since this would guarantee the stable flows investment and technologies into the country. This would lead to the further development of the modernisation program of China's armed forces.

China considers weakened Russia not a rival, but a possible partner, which potentially could guarantee the stable supply of energy resources and weaponry. The growing Russia's market is considered as an export market by China. The Chinese strategic thinkers consider Russia as the potential geopolitical counterweight to the US ${ }^{23}$.

China needs the favourable European position as well, to use it as a lever in the various negotiations with the US. China is interested in the emergency of the EU as the united geopolitical actor, which has the potential for balancing the power of the US. Europe is considered as the giant market for Chinese production, the source of modern technology and the source of investment and the possible supplier of modern weaponry to China as well ${ }^{24}$.

\section{The Strategies of the Global Geopolitical Actors towards Eurasia}

\subsection{The Geopolitical Strategy of the US towards Eurasia}

US politicians and strategic thinkers mainly agree on the goal of the general (grand) strategy of the US. This is the preservation of the hegemony of the US and the unipolar international system. There is the common agreement on the main interests of the US in Eurasia - prevention of emergency of the anti-American geopolitical bloc in the continent. However, the US strategic thinkers disagree on the practical

\footnotetext{
${ }^{21}$ Nunn S., Schlesinger J.R., The Geopolitics of Energy into the 21st Century, Vol. 3, Center of Strategic and International Studies, 2000, p. 21

${ }^{22}$ Liang $Q$., Xiangsui $W$., $A$ Chinese Alternative to US Hegemony, htttp://www.heartland.limesonline.com, 05102004.

${ }^{23}$ Smith M., "A Current Russo-Chinese Relations", Working paper F81, Conflict Studies Research Centre, January 2003, http://www.csrc.ac.uk, 03042004.

${ }^{24}$ Liang $Q$., Xiangsui $W$., (note 22).
} 
means and ways to implement these strategic goals, despite the almost common agreement on the necessity of the active prevention of revisionism ${ }^{25}$.

There are two main interpretations of general (grand) strategy of the US. The first one is the strike on the potential revisionists in order to establish the hegemony of the US further. The second one is the inclusion of the potential revisionists, i.e. the creation of global collective security system through multilateral security institutions. Both strategies belong to the type of the strategies of active prevention. These two views of the formation of the foreign policy of the US represented by the neoconservative (the proponents of the first alternative) and by the neo-liberal (the proponents of the second one) groups of American elite (both Republicans and Democrats) respectively ${ }^{26}$. Both strategies of passive containment of revisionists and isolationism are not popular among the US foreign policy elite (especially after the attacks of September 11).

The neo-conservative administration of the President G.W. Bush undoubtedly implements the offensive strategy of the containment of the potential revisionists and the establishment of the global hegemony of the $\mathrm{US}^{27}$. Both neo-conservatives and neo-liberals agree on the main threats to the interests of the US in Eurasia. The threat to the geostrategic and long-term interests of the US would arise in the case (according to the one of the most famous present US scholars of geopolitics from the neo-liberal camp Zbigniew Brzezinski):

- the countries of Central Eurasia unite themselves and became an active actor hostile to the West, or even worse

- they extende their influence to the South Eurasia or create an alliance with one of the great powers in East Eurasia or

- the two great East Eurasian powers somehow merge together or

- the Western allies of the US distance them and create an alliance with the powers of Central Eurasia

The neo-conservative strategic thinkers like the former deputy secretary of defence Paul Wolfowitz and the former chairman of Defence Policy Board of Defence Department Richard Perle have a similar vision of the threats ${ }^{28}$.

\footnotetext{
${ }^{25}$ Rice C. "Promoting the National Interest", Foreign Affairs, 79 (1), 2000, p. 45-62; Nye J. "Redefining the National Interest", Foreign Affairs, 78 (4), 1999, p. 22-23.; The Commission on America's National Interests, “America's National Interests” 2002 June. http://bcsia.ksg.harv`ard.edu/ BCSIA content/documents/AmerNatInter.PDF , 22102004.

${ }^{26}$ Posen B. ., "Trans-Atlantic differences: a clash of values or a failure to face reality?", http:// www.theepc.be/challenge/challenge detail.asp?SEC $=$ challenge \& SUBSEC $=$ is sue $\&$ SUBSUBSEC $=\&$ REFID $=964,1011^{-}$2002; Gaddis J.L., "A Grand Strategy", Foreign Policy, Nov-Dec, 2002, http://www.foreignpolicy.com/issue novdec_2002/gaddis.html, 1211 2002; Bacevich A.J., "The Irony of American Power", First Things, 81, 1998, p. 19-27, http://www.firstthings.com, 16082004.

${ }^{27}$ Gaddis J. ., "A Grand Strategy", Foreign Policy, Nov-Dec, 2002, http://www.foreignpolicy.com/ issue novdec 2002/gaddis.html, 1211 2002;

${ }^{28} 1992$ "Defence Planning Guidance" Draft Excerpts, http://www.emjournal.pwp.blueyonder.co.uk/ may03101.html, also look, Perle R., Frum D., An End to Evil: How to win the War on Terror, New York: Random House, 2003.
} 
The geostrategy of the US is to prevent potentially revisionist states or their coalitions from taking the control over the geostrategic zone of Eurasian rimland and prevent the alliances which could achieve this control by preserving the geopolitical plurality in the Eurasia. Americans fear the direct strategic subjugation of CIS countries to Russia, the success of the geopolitical alliance between Russia and Iran or Russia and China, the alliance between China and Japan (possibly including ASEAN states) in East Asia, the alliance between China and Islamic countries, i.e. the Eurasism. The US fears the alliance among European continental states and Russia, i.e. Eurocontinentalism as well ${ }^{29}$.

The measures suggested by the neo-conservatives for the neutralisation of the threats to the interests of the US in Eurasia essentially differ from the ones suggested by the neo-liberals. Brzezinski had formulated the active strategy of mondialism, which purposes are the prevention of the processes negatively affecting the US and the creation of the global transcontinental collective security system led by the US in the long-term. The action plan proposes to:

- prevent the plot (rebellion) by the US allies, keeping them dependent on mutual security system with the US

- assure the security of US citizens and the security of the countries, which are under influence of the Americans

- prevent the political alliance among countries hostile to America

- convert the hostile countries into allies ${ }^{30}$

Neo-conservative approach is highlighted in the new National Security Strategy of the United States. It is directed to transform the US into global "hyper-state", whose hegemony would be guaranteed through the giant difference of concentrated power, pre-emptive strikes on potential enemies and radical geopolitical transformation of the Middle East instead of the leadership over the collective security system and the containment of revisionist states.

According to the neo-liberals, the security guaranties to Germany and Japan is one of the most important elements of the long-term strategy of the US towards Eurasia. America co-opts the potentially revisionist states into the pro-status quo camp by guaranteeing the security and opportunities of economic development for them. The foreign policy of the US under administration of W.Clinton was based on the Brzezinski's strategic concept towards Eurasia. The regional balance of the power and the regional collective security systems preventing the formation of the antiAmerican coalitions had guaranteed the stability in the main geostrategic regions. The stability was ensured through the NATO in Europe, through security guaranties to Japan, South Korea and Taiwan in East Asia and through support of Israel and Gulf States in the Middle East.

According to the neo-liberals, the US should project the transcontinental security system controlled by them in order to preserve geopolitical pluralism in Eurasia and prevent the hostile alliances of alternative centres of power as well in the longterm (until 2035) 31 $^{31}$ Transcontinentalism suggests the common security system (com-

${ }^{29}$ Brzezinski Z., (note 5) p. 54.

${ }^{30}$ Ibidem, p. 54-72.

31 The article considers 2005 - 2035 (thirty years) the long-term, 2005 - 2020 (15 years) the midterm and 2005 - 2010 the short-term period. 
munity) over all the Northern Hemisphere. Brzezinski suggests that the US should become the political unifier of the civilized world by creating the transcontinental security system of "North" (US-EU-Russia-Japan). The transcontinental union of liberal democracies would lead the world and the US would lead the union. Westernizing and attracting of Russia to the side of the US is very important, since this would prevent the formation of effective alliance between Russia and China or between China and Islamic civilization ${ }^{32}$.

The possibility to form something similar to the four-lateral union of Austria, Great Britain, Prussia and Russia, which existed after Vienna Congress in 19thcentury, is also discussed among US political scientists. The new coalition of the beginning of 21st century would consist of the US, the EU, Russia and Japan ${ }^{33}$. This alliance should eventually constitute the premises for China's integration into this transcontinental security structure ${ }^{34}$. The transcontinental geopolitical alliance uniting global "North" from Vancouver to Vladivostok would be directed against the Islamic world and the remaining "South" (and China, if its inclusion would fail).
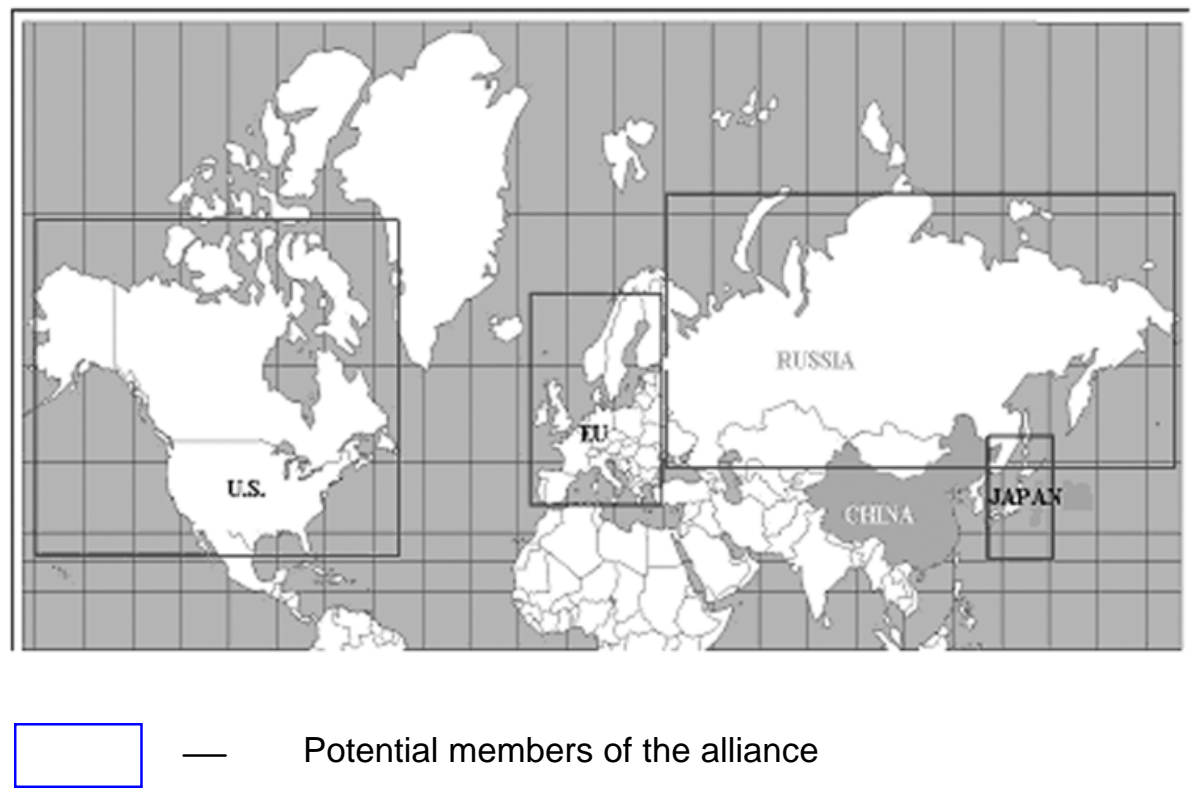

Map 1. Transcontinental alliace: US, EU, Russia, Japan

\footnotetext{
${ }^{32}$ Brzezinski published three articles in The National Interest during 2000 - "Living with China" (2000 Spring), "Living with a New Europe" (2000 Summer) and "Living with Russia" (2000 Fall) on this issue.

${ }^{33}$ Kissinger H. Where we will turn now? The Washington Post, 0611 2001; Barber L. The split among great European powers, Financial Times, 0611 2001; Allison G., Kaiser K. and S. Karaganov, The world needs a new security alliance, International Herald Tribune, 21112001.

${ }^{34}$ Brzezinski Z., The Geostrategic Triad. Living with China, Europe and Russia, Washington: The CSIS Press, 2001, p. 23-24.
} 
The actual forms of the institutionalisation of this union could vary. The transformation of the Organization of Security and Cooperation in Europe (OSCE) into Organization of Security and Cooperation in Eurasia by incorporating the Asian countries, which do not belong to OSCE into it, could be one of the ways. NATO could be expanded and transformed into the main pillar of the new international security system in the future as well. Russia would gain more weight through these organizations in international politics, but it would become more constrained at the same time. The deepening of integration in the EU and the strengthening of common defencse forces would slow down. The EU should stay a political confederation. This would be like the peculiar repetition of the strategy of the US directed at "keeping Germans down" after World War II. Germany was included into almost every Western international institution after this war.

The neo-conservatives, differently from liberals, are sceptical about guaranteeing the hegemony of the US through the bounds of the collective security. The geostrategy of neo-conservatives can be described by four concepts:

- military supremacy

- pre-emptive strike

- global sovereignty

- global governance

Bush administration had chosen to strengthen of the US relative power based on weapons system of the new generation technology, adoption of non-military informational technology, nanotechnology and biotechnology in industry and the control of energy resources supply and transportation routes. This strategy is based on The National Security Strategy of United States of America ${ }^{35}$, which authorship is assigned to the neo-conservatives. The success of it would make the American military supremacy and economical potential eventually unmatchable ${ }^{36}$. The US should maintain the rapid growth of its power and significantly increase the gap between the power of the US and the power of the other countries or even regional blocs. According to the plans of neo-conservatives, the US should become so powerful that it could be independent of allies' support ${ }^{37}$ maintain the control over space and oceans and could secure the territory of North America from attacks carried by missiles or other non-conventional weapons. However, the achievement of qualitative changes, i.e. global political influence and unquestionable international prestige is the main condition of guaranteeing the hegemonic dominance ${ }^{38}$.

${ }^{35}$ The National Security Strategy of the United States of America, September, 2002.

${ }^{36}$ New The National Security Strategy of the US is preventively interventionist. It suggests to neutralise the threats to the US in its beginning, therefore, declares the possibility to use unilateral preventive measures including pre-emptive strikes. Also see Statkus N., Motieka E., Globalios ir Baltijos valstybiu geopolitinès situacijos pokyčiai, Lietuvos metine strateginé apžvalga 2003, Vilnius: Lietuvos Karo Akademija, 2004, p. 9-53.

${ }^{37}$ The 21 active tactical brigade of the 33 were outside the borders of the US (16 were in Iraq, two in Afghanistan, two in Korea and one in Balkans) in the mid of 2003. Only 12 brigades are left for other possible military operations, so the help of the allies is necessary for the US in order to carry on two or more military operations globally, see Hutchison K. "Stretched To Thin", Washington Times, 20 August 2003.

${ }^{38}$ Barry T., "A Strategy Foretold”, Foreign Policy In Focus, Policy report, October 2002, http:// www.fpif.org/papers/foretold body.html; Pieterse J. N., "Neoliberal Empire", Theory, Culture \& Society, 21, 3, 2004, p. 119-140. 
The US may take unilateral actions and also organise the effective international coalitions with clear goals for the sake of securing its national interests The National Security Strategy of the United States insist. According to the authors of the Strategy, every single state is responsible for the ongoing processes in its territory, which disturb the international order maintained by the US. If any state could not carry on its international obligations its sovereignty could be infringed for the sake of neutralisation of the source (or sources) of the threats. ${ }^{39}$ The implementation of the Strategy could eventually lead to the establishment of global sovereignty of the US, which means that the states maintain the right to freely administer their territory until their activities (or passivity) do not interfere with the interests of the US. Therefore, the US should, whether willingly or not, establish the permanent global governance system in order to implement the Strategy. The organizations of terrorists operate in many countries (e.g. al-Qaeda units exist in about 60 countries), so the US would be forced to execute the open and secret operations against such organizations in the territory of sovereign states despite of those states permission in order to destroy such organizations. Majority of states support the fight against terrorism and co-operate with the US, but Americans, in order to be sure of the sincerity of such co-operation, should increase the monitoring of the institutions of other states, especially on the security and force structures and interfere or even take the control over them if necessary. The ongoing reform of the US armed forces confirms this statement.

In essence, the Pentagon had confirmed the doctrine of a permanent war. The military conflicts could emerge in any place of the globe. According to neo-conservatives, the US should be ready to send its "expedition forces" rather quickly. The Pentagon plans to return home as many soldiers as possible (this is based on economical calculations), because the prediction of future conflict turmoil could be more difficult and these conflicts could emerge more evenly contrary to the period of the Cold War. The extension of the US deployment capabilities, i.e. strengthening the air transport, creation of "forward" bases in the places of strategic importance, which could be quickly converted into real bases for the dislocation of significant amount of the soldiers is planned. These "forward" bases should be created and there should be more of them in the strategically important crossroads of the global transportation and communication routes. This means that the significance of the states controlling the strategically important crossroads of transportation and communication increased in the US foreign policy. ${ }^{40}$

A new generation information based space technology weaponry systems (the new antiaircraft defence system, Falcon $^{41}$ program of building up the new offensive weapons in next 25 years like an supersonic drones, missiles, and bombs, launched from the space ${ }^{42}$ ) would effectively secure the territory of the US and provide the

39 The National Security Strategy of the United States of America, September, 2002.

40 "On imperial overstretch. Can the USA afford to send troops here, there and everywhere?", Jane's Foreign Report, 2748, 7 August, 2003.

${ }^{41}$ Force Application and Launch from the Continental US.

${ }^{42}$ The Project for the New American Century, "Rebuilding America's Defenses. Strategy, Forces and Resources for A New Century, 2000, http://www.newamericancentury.org/ RebuildingAmericasDefenses.pdf; Pieterse J. N., "Neoliberal Empire", Theory, Culture \& Society, 21, 3, 2004, p. 119-140. 
possibilities for the armed forces of the US to execute military operations without allies or military bases in other continents. The geostrategic goals of neo-conservatives are very different from those of neo-liberals. The neo-conservative's strategy for the establishment of hegemony and ruination of revisionists focus its entire attention on the space control and the transformation of the continent of North America into the "citadel" of the power of the US. Eurasia will loose its exceptional geostrategic importance to the US (and would become equally important as the other continents) in case this strategy is implemented.

However, the US should direct its main focus towards the discontinental geostrategical zone of Eurasia until these goals are achieved and the positions of neoconservatives and neo-liberals are similar in this case. Though, contrary to neo-liberals, neo-conservatives are not intended to form the collective security alliances. Their strategy is the achievement of the ultimate military supremacy, which would deter potential enemies so, that they could not even think about any possibility of successful stand against the US. However, the US could antagonise the potential rivals (the EU, Russia, China) through the system of indirect balancing separating the EU from Russia and China from Russia and the Middle East (by expanding it's own influence in this "shatterbelt zone") and also through employing the tactics of the selective finding of the allies (e.g. the United Kingdom, Japan, Australia and, probably, India) ${ }^{43}$ in the case the deterioration would not work. The US should prevent the increase of the relative power of Russia and China as well.

The united pro-American Europe is the main factor guaranteeing the US interests in Eurasia (either minimal or long-term ones) according to the neo-liberals. The US should preserve the continental European states as the trustful allies in NATO and this is the main condition of the existence of transcontinental alliance. These allies should stay basically dependent on the collective euroatlantic defence system organised by the US. At the same time the increasing of their defence budgets and development of their own specialised military capabilities would be desirable. The allies should subordinate their political and economic interests for the sake of global security policy of the US ${ }^{44}$.

It is very important to the US to strengthen the Euroatlantism as the main axis of projected transcontinental alliance (and the potential buttress against Russian expansion in the case of the failure of this project). Russia could be bound with the West institutionally by the co-operation instruments of the EU and NATO, therefore forming the opportunities and incentives to it for joining the future transcontinental alliance ${ }^{45}$.

In short-term and mid-term, the interests of the US towards the EU would be the deeper integration of the Union, the increase of its military expenditures, the capability of its armed forces to interact with the armed forces of the US, the European support for the anti-terrorism campaign and the successful integration of new

${ }^{43}$ Layne Ch.,"Offshore Balancing Revisited", The Washington Quarterly, 25, 2 , p. 233-248.

${ }^{44}$ Ibidem, p. 41; The Atlantic Council of the United States, "Permanent Alliance? NATO's Prague Summit and Beyond", Policy paper, April 2001.

${ }^{45}$ Asmus R. ., Pollack K.M., The New Transatlantic Project, Policy Review, October-November 2002, http://www.policyreview.org/OCT02/asmus_print.html, 06102002. 
member states preserving their pro-American attitudes ${ }^{46}$. According to certain American strategic thinkers, the new members of the EU from Central and Eastern Europe may positively contribute on the creation of pro-American EU confederation. ${ }^{47}$ In fact, the centralisation of the EU to a certain degree (in the fields of foreign policy and defence especially) is useful for the US unless it is not directed against the global and regional politics of the US. The support of the centraliseed European diplomacy for the global geopolitical projects of the US and the American politics in the Middle East or Central Asia would be very helpful. Americans also wish the united and effective security and foreign policy of the EU, which could contribute to the expansion of the capabilities of NATO. Other geopolitical actors (Russia, China) would face the complications in implementing their balancing politics, if the EU would become pro-American and centralised confederation. On the other hand, less centralized EU would provide more freedom of balancing if the situation would become less favourable to the Americans.

The neo-conservatives may even try to contain (isolate) the spread of influence of continental European states, China and Russia in Eurasia, because they do not attach to the long-term security alliances and aims at the further strengthening of unipolarity. The US had formed the zone of pro-American countries and the net of American military bases by incorporating the Central European states in NATO together with Romania and Bulgaria (there they plan to dislocate a part of their forces, which are in Western Europe at the moment), by altering the geopolitical orientation (towards the US) of Georgia and Azerbaijan, by military presence in Iraq and Afghanistan, by allocating troops in Uzbekistan and Kyrgyzstan and by enhancing the strategic partnership with India. This zone should prevent the geostrategic convergence between Russia and the EU (and maybe China), the spread of Russian influence beyond the boundaries of heartland and the regional expansion of $\mathrm{China}^{48}$. Thus Bush administration had created the conditions for the balancing the power of the EU, Russia and China and rivalry among them but also a threat of potential confrontation with any of these geopolitical subjects.

The point of departure of the US politics towards Russia in the short-term and mid-term is the same for both the neo-conservatives and the neo-liberals. Neither Russia nor the US are interested in the radical change of their status in the international arena in the short-term. The US does not want the total withdrawal of Russia from the CIS or the possible disintegration of it. The split of Russia into separate parts would allow the spread of influence of the EU into the Western part of Russia and CIS and would even more activate China's expansion to East Siberia and Russian Far East. Russia do not wish the rapid decline of the influence and global power of the US despite its rhetoric about multipolar world, since it would allow the EU and China emerge as the alternative power centres in the international system before Russia would recover military and economically. The rapid consolidation of power of China and the EU could be disadvantageous to Russia's interests in the CIS supraregion,

${ }^{46}$ Hunter R. E., Europe's Leverage, The Washington Quarterly, 27, 1, 2003, p. 91-110.

${ }^{47}$ Asmus R., Paper presented in discussion-seminar "Lithuania's Role in the Region: View from the USA", Vilnius University, Institute of International Relations and Political Science, 27092004.

${ }^{48}$ Pieterse J. N., "Neoliberal Empire", Theory, Culture \& Society, 21, 3, 2004, p. 119-140. 
which Russia considers strategically important and this could harm the integrity of Russia in its Far Eastern and East Siberian subregions as well. Even if Russia would formally preserve its sovereignty, the Western and Eastern parts of the country possibly could begin to gravitate towards the totally different geopolitical subjects the EU and China. Therefore, the conditions for the convergence of Russian and American short-term interests in the beginning of 21st century and especially after September 11 had emerged.

Both countries face the same threat (the Islamic fundamentalism) and both have the same geopolitical rival - China ${ }^{49}$. There are some common geoeconomic interests too: Russia is important to the US as an alternative supplier of strategic resources independent from Islamic countries and Russia is interested in co-operation with the West and particularly the US, since the openness to them is one of preconditions to the Russia's successful economic modernisation. Therefore the US seek the increase imports of gas and oil from Russia, the openness of Russian energy and mining sectors to the American capital and the increasing Russia's economic dependence on the export of energy resources. Americans also support the cut of Russian armed forces and their reform in order to make these forces more interactive with the armed forces of NATO, but also aims that these reformed forces could effectively operate only on regional level ${ }^{50}$. The US are interested in preserving the centralized structure of Russia, which could guarantee the operation of Russian democracy, the process of economic and military reform, the security of foreign investments and the stable supply of energy resources. Therefore, the US is interested in co-operation with Russia, but not in equal strategic partnership. ${ }^{51}$

The US strategic thinkers plan to co-opt Russia into the projected transcontinental security system, which should guarantee the prevention of the power spread of China. This co-optation is planned after Russia would eventually become the regional power. ${ }^{52}$ There would be no more need of united Russia and the US could support disintegration processes in Russia striving for the ultimate overtake of continental geostrategic zone (the heartland) in case the strategy of containment of China would work, i.e. China would become pro-American or disintegrate ${ }^{53}$.

The control of Pacific, similarly to the domination in the Atlantic, is important to the US in order to secure North American continent from the side of Asia. The fundamental threat to the US geostrategic interests in the East and Southeast Asia and the Pacific is the success of China in becoming the dominating power in the region and both the neo-conservatives and neo-liberals agree on this. The rapid economic development of China, the modernisation programs of its military forces, the creation of the space exploration forces (the first Chinese manned spacecraft was launched in October 2003) and the enhancing Chinese influence on the ASEAN countries worries the US political elite ${ }^{54}$. The US is forming the system of preventive anti-Chinese alliances in East Asia in respon-

${ }^{49}$ Russett B., Stam A., (note 20).

${ }^{50}$ The Atlantic Council of the United States, The Centre for European Reform, and The Institute for the U.S. and Canadian Studies at the Russian Academy of Sciences, "The Twain Shall Meet: The Prospects for Russia-West Relations”, Policy paper, May 2002, http://www.cer.org.uk, 14092004. ${ }^{51}$ Danilov D., EU-Russia positioning in the changing security field, http://www.theepc.be/challenge/ topdetail.asp?SEC $=$ documents $\&$ SUBSEC $=$ issue \& REFID $=824,10062002$.

${ }_{52}$ Brzezinski Z., (note 34) p. 68-71; Russett B., Stam A., (note 20).

${ }^{53}$ Valle del A., The American strategy in Eurasia and the consequences of the war in Kosovo, International Institute of strategic studies, http://www.strategicsinternational.com/enuseurasie.htm

${ }^{54}$ Sutter R., Why Does China Matter? The Washington Quarterly, 27, 1, 2003, p. 75-89. 
$\mathrm{se}^{55}$. The US enhances the military co-operation with India ${ }^{56}$, strengthens strategic bounds with Japan, Australia ${ }^{57}$ and Singapore ${ }^{58}$. The next steps of the US possibly could be slowing down the economical development of China, blocking its political influence and changing its internal situation through propagating of democratic ideas.

The neo-liberals expect that the economic growth of China would transform its political system into democracy in long-term. The democratisation of China would possibly create the favourable conditions for its inclusion into projected transcontinental security system. The neo-conservatives suggest that the rich industrial shore regions would not be satisfied if the democratisation would not occur and this will lead to the internal instability of China. However, at that time the US shall be prepared to secure its territory from possible China's inter-continental missile attack, which could occur in the case of political turmoil there ${ }^{59}$.

\subsection{Russia's Strategy towards Eurasia}

Russia is rather weak and incapable to confront great maritime powers, especially the US. Despite the loss of former influence in Central Asia and Mongolia, Russia still practically controls the territory of the heartland. The geostrategic location of Russia remains important, but its geopolitical situation is unenviable. In the West, Russia borders an enlarged EU with its population of about 454 million and with its economy about 10 times lager than Russian one. In the South, Russia is surrounded by Islamic countries with the population of 300 million and by China with the population of 1.2 billion and four times bigger economy ${ }^{60}$. However, considering Russia as a weak and non-influential state would be a mistake, because it has about 2,000 nuclear missiles and still is the only country in the world, which is capable of maintaining the balance of mutual assured destruction with the US.

Vladimir Putin, the current Russia's President, and his team perceive the advantages and disadvantages of their country well. They realise the fact that today Russia could pursue more or less secure development and move towards modernisation only by associating itself with most developed countries, i.e. the West ${ }^{61}$. Russia could neither challenge the US with its power, nor incite other countries against it anymore ${ }^{62}$. Therefore, Russia dropped open confrontation and even began to co-operate with the US in

${ }_{55}$ How ASEAN can hold its own against China, The Straits Time, http://straitstimes.asia1.com.sg/ home $/ 0,1869,, 00$. html

56 "On imperial overstretch. Can the USA afford to send troops here, there and everywhere?", Jane's Foreign Report, 2748, 7 August, 2003.

${ }^{57}$ Blank S., "Toward a New U.S. Strategy in Asia", http:/www.carlisle.army.mil/ssi/about/2004/feb/ feboped.pdf

${ }^{58}$ The US and Singapore establish new strategic defense and security ties, Radio Singapore International 22 October, 2003.

${ }^{59}$ Johnson A.I., Realism(s) and Chinese Security Policy in the Post-Cold War Period, in Kapstein E.B., Mastanduno M., Unipolar politics: Realism and state strategies after the Cold War, New York: Columbia University Press, 1999, p. 261-318.

${ }^{60}$ Brzezinski Z., (note 34) p. 74.

${ }^{61}$ Kobrinskaya I., Russia's Security Agenda vis-ą-vis Transatlantic Developments after the War in Iraq, PONARS Policy Memo 320, Center for Strategic and International Studies, http://www.csis.org/ ruseura/ponars/policymemos/pm_0320.pdf

${ }^{62}$ S. Neil MacFarlane, Russia, the West and European Security, Survival, vol.35, no.3, Autumn 1993. 
the frame of anti-terrorist coalition. Russia needs the US as an ally in curbing Islamic radicalism and balancing China and the US needs Russia for the same purposes ${ }^{63}$.

The first Russian step towards achieving its geostrategic interests should be the restoration of the full control over the continental zone (heartland), i.e. the reintegrating of CIS and regaining its influence in Central Asia and strengthening the internal centralisation of the country as well ${ }^{64}$. The second step is guaranteeing at least a neutral position or buffer state status of the Southern and Western hinterland's parts (to South Caucasus and Western CIS states) in the discontinental geostrategic zone (the rimland). Such a short-term strategy should unavoidably lead Russia into conflicts with the EU (mainly because of its project "Wider Europe") and the USA ${ }^{65}$. Therefore, Russia aims not only to prevent the spread of the influence of the US and other Western states and their dominated international organizations in the Western part of the CIS (in Eastern Europe), but also aims to strengthen the geoeconomic and geoenergetic dependence of Central Europe and the Baltic States on Russia. If the circumstances become favourable, then Russia will try to transform some of Eastern European countries and the Baltic States into the agents of its influence in transatlantic and the EU institutions through its economical and energetic influence on them. Russia plans to use them for dividing the EU and weakening transatlantic relations and for supporting political and economical decisions of NATO and the EU that are useful to it. ${ }^{66}$

Russia considers NATO dominated by the US as the structure cutting off the way for the enhancement of its power in Europe and as eventual serious threat to the region of its Western and Southwestern borders. Currently Russia avoids confrontation with NATO, because it realises that the main current threats to Russia rise both from the South and the East. Therefore, Russia considers the US and NATO as a tactical ally now, but only in a Realpolitik sense ${ }^{67}$.

While co-operating with NATO, at the same time Russia expects to achieve some power erosion in this organization. Russia aims to weaken the link between Europe and the US and to incite NATO's evolution from the military defence organization to a more political one, eventually expecting to slow down or even stop the NATO's further expansion into Eurasia through participation in NATO-Russia Council ${ }^{68}$.

This Russian foreign policy could be described as strategy of adjoining the most powerful country in the world expecting to form necessary conditions for the restoration of Russian power through the alliance in the area of former Soviet Union. In other words, Russia expects the bufferisation of former Soviet countries. However, it seems that such strategy did not work and was fruitless. The last few years after September 11 indicate the decline of Russia's international position and its influence in the CIS countries (except their increasing dependence on Russia's energy resources). The US and its allies control Iraq and most of Afghanistan. The Russian companies were not allowed to participate in rebuilding of Iraq. Also, the possibilities in the

${ }^{63}$ Kobrinskaya I., (note 61).

${ }^{64}$ Sushko O., The Dark Side of Integration: Ambitions of Domination in Russia's Backyard, The

Washington Quarterly, 27, 2, 2003, p. 119-131.

${ }^{65}$ Kobrinskaya I., (note 61).

${ }^{66}$ Bugajski J., "Russia's New Europe", The National Interest, 2003/2004 Winter.

${ }^{67}$ Smith M., A., "Russia \& The West", Working paper F78, Conflict Studies Research Centre, July 2003, http://www.csrc.ac.uk, 12082003.

${ }^{68}$ Laurinavičius, Č., Motieka E., Statkus N., (note 7) p. 332. 
exploitation of oil fields of this country, despite the contracts with Hussein's government, for Russian companies remain unclear. In the Middle East, the pro-Soviet and pro-Russian countries like Iran, Libya and Syria have been forced to co-operate with the US. The US has established the military bases in Uzbekistan and Kyrgyzstan. The Baltic States, Slovakia, Romania and Bulgaria have joined NATO and the US intends to establish its military bases in some of these countries ${ }^{69}$.

The turn towards co-operation with the US probably was the one phase of a long-term Russian geopolitical Eureasianist strategy in Russian foreign policy. Russia's co-operation with the US has weakened the transatlantic connection and has incited unilateralism of the US and the rivalry among West European great powers. The unilateral actions of the US incited France and Germany to establish closer relations with Russia including it automatically in European affairs ${ }^{70}$. Such development forms the possibilities for Russia to weaken further the transatlantic connection and attempt to ruin the influence of the US in the whole European sub-continent by shifting the geopolitical orientation of continental European states.

Russia would be interested in the decline of influence of the US on the Eurasian coastlands in the mid-term period. Therefore Russia is satisfied with every sign of the disagreements into Euroatlantic relations and with any efforts of the EU to emerge as the independent global centre of power. However, Russia is not interested in the EU independence in the long-term period. Russia would like to participate in the formation of the "new multipolar world order" demand the strategic subjugation of Europe in a long-term perspective. Russia should make the efforts in closely connecting with the EU in energy, economy spheres and through the net of common political institutions where the US is not involved. Though, at the same time Russia should also avoid entering the EU and needs to preserve the full sovereignty of internal politics during short-term and mid-term periods.

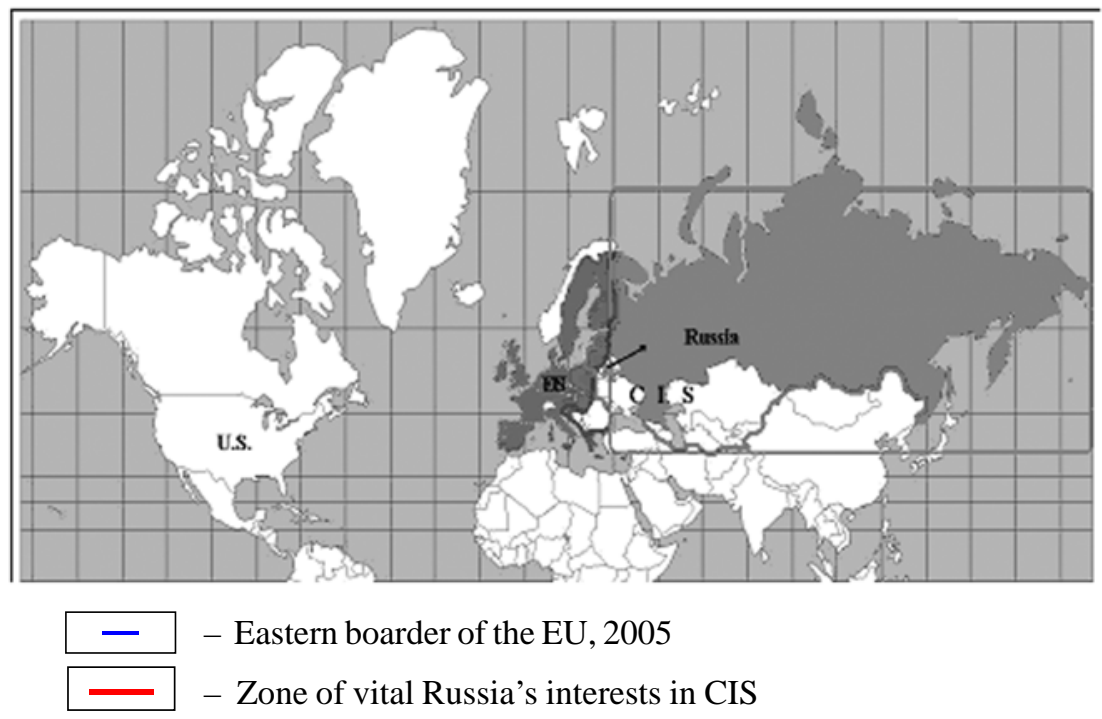

Map 2. Russia's vital interests in CIS 
Russia expects to receive financing from the EU for renovation of its transportation structure, strengthening its Southern borders security, arrangement of its citizens passports, ratification of readmission treaties and for the other means, which would provide the opportunities to integrate Russia into the Schengen system. Russia is very interested in the plans for common European defence system. Russia considers the possibilities of the development and renovation of its military industry on the one hand, and for the decline of the military importance of NATO on the other. That also means the decline in the USA's military involvement in Europe in those plans.

The goals mentioned above are in fact reflected in another form in The Midterm Strategy of Russian Federation and the EU (2000-2010). The conception and projects of the four common spaces of Russia and the EU (the Common European Economic Area, the freedom, justice and security area, the area of science and education, the common external security area), which should guarantee the achievement of goals mentioned above by Russia ${ }^{72}$.

Russia tries to implement its policy towards Europe through the construction of very close relations with the largest EU member-Germany, in order to achieve the strategic partnership with the EU. Russia supposes the qualitative changes in the Russian-European relations by using the support of Germany. Germany tends towards strategic partnership with Russia too, because this would help to implement Germany's balancing politics ${ }^{73}$. Germany is the main partner of Russia's foreign trade with 10 per cent share of its export and import in 2002. Russia supplies 25 per cent of Germany's petroleum demand and about one-third of its gas demand ${ }^{74}$. Germany is Russia's main creditor and has the main share of investments in this country ${ }^{75}$. Russia is removing the barriers to German investments; e.g. Putin has announced that restrictions on the sale of Gazprom stocks will be cancelled for German E.ON, which controls only 5-6 per cent of Gazprom stocks so far ${ }^{76}$.

Russia would also be interested in instability in the Middle East, in case it could prevent the threat of radical Islam successfully. The stack of the US in the Greater Middle East would be favourable for Russia too. The instable situation in the Middle East would keep the high petroleum prices, raise Russian oil and gas export and would increase Russian foreign currency reserves necessary for the country's debt payments and technologic renovation of industry. The instability in the Middle East would require a lot of attention and resources of the US and, therefore, its attention on Western CIS countries and South Caucasus would be reduced. However, Russia does not wish the establishment of Islamic fundamentalist regimes in the Middle East, because it could threaten the security of its Southern borders ${ }^{77}$.

\footnotetext{
${ }^{69}$ Barysch K., Kekic L., Putin should tilt toward the EU, International Heral Tribune, 16, 06, 2003.

${ }^{70}$ Voronov K., Russian diplomatic revolution, Nezavisimaja Gazeta, 9, 04, 2002.

${ }^{71}$ Smith M. A., (note 67).

${ }^{72}$ Lynch D., Russia's Strategic Partnership with Europe, The Washington Quarterly, 27, 2, 2003, p. 99-118.

${ }^{73}$ Komitet "Rosija v objedenionoi Evrope", "Kak uglubit sotrudnichestvo Rossii i Evropeiskogo Sojuza, Moscow, 2003; Schroeder G., "Rosija i Germanija: leitmotiv sotrudničestva', Rosija v globalnoi politike, 2, 4, 2004, p. 68-77;

${ }^{74}$ Smith M. A., (note 67).

${ }^{75}$ Gvosdev N. K., The Future Orientation Of Russia: Let The Bids Begin, In the National Interest, October 2003, http://www.inthenationalinterest.com

${ }^{76}$ Rar A., "Pochemu Schroederu nravitsia Rosija", Rosija v globalnoi politike, 2, 4, 2004, p. 77-83;

77 Smith M., Russia and The Middle East, Working paper F79, Conflict Studies Research Centre, September 2002, http://www.csrc.ac.uk, 18022003.
} 
Principally Russia is interested in establishing the close political and economical ties with China. Russia needs China as an important regional power limiting the hegemony of the US in a short-term and mid-term. China is the growing market for the export of Russian weaponry and natural resources. However, the slowdown of growth of Chinese power and the relative isolation would be useful for Russia in order to avoid the threat of ever growing China's potential to Russia's Far East and Eastern Siberia in the mid-term. Russia tries to limit the Chinese immigration to Russia's Far East and to prevent the growing economic dependence of this region on China. Russian Far East and Eastern Siberia are sparsely populated and rich in the natural resources. Therefore, some Russian analysts suggest that such circumstances provide the opportunity for the aggressive expansion of China towards it ${ }^{78}$. There are about 2.5 million Chinese in the region, the total population of which is only about 6.7 million $^{79}$.

Russia should be interested in ousting the US from Eurasia in the long-term perspective. The creation of the pan-Eurasian security system through strategic partnership with the EU, China and some South and East Asian states would allow achieving that ousting. Russia would have an important role in such a pan-Eurasian security system ${ }^{80}$.

\subsection{The Strategies of the Main Powers of the EU towards Eurasia}

The EU still is not a geopolitical subject or a real actor in international relations. The EU's foreign policy is the projection of the foreign policies of its member states. The geostrategy of the EU can not exist until there is absence of really common foreign and security policy. This does not mean the absence of political projects aiming to transform the EU into the geopolitical subject, with its own geostrategy.

The debates on the materialization of the EU as the subject of international relations have begun in the academic and political circles ${ }^{81}$. There are two main geopolitical paradigms about the place of the EU in the international system and its relations with other geopolitical subjects. Those paradigms are Euroatlantism and Eurocontinentalism and the debates on future of the EU develop in these frames.

The Euroatlantism is the European version of the American neo-Atlanticism geopolitical thought ${ }^{82}$. The proponents of the Euroatlantism consider Europe and the US as inseparable parts of Western civilization. Those parts are united by close economical, cultural, social, political and security interests and, therefore, the transatlantic strategic unity should be maintained and strengthened. EU's foreign and security policy should be orientated to the implementation of common interests with

\footnotetext{
${ }^{78}$ Smith M., “A Current Russo-Chinese Relations”, Working paper F81, Conflict Studies Research Centre, January 2003, http://www.csrc.ac.uk, 03042004.

${ }^{79}$ Gorenburg D., "The 2002 Russian Census and the Future of the Russian

Population", PONARS Policy Memo 319, Center for Strategic and International Studies, http:// www.csis.org/ruseura/ponars/policymemos/pm_0319.pdf

${ }^{80}$ Dugin A. Osnovy geopolitiki, Moskva: Arktogeja-centr, 1999.

${ }^{81}$ Further see Bretherton Ch., Vogler J., The European Union as a Global Actor, London: Routledge, 1999, p. 1-45.

${ }_{82}$ Statkus, N., Motieka, E., Laurinavičius, Č., (note 2) p. 36-38.
} 
the US and it must not harm, dub or even subvert this unity ${ }^{83}$. However, the Euroatlantists are not satisfied with the current passive role of the EU member states in the defence policy and, therefore, speak out for better co-ordination of CFSP and for the increasing the potential of ESDP. Anyway, according to the Euroatlantists, the processes mentioned above must neither dub NATO nor diminish the transatlantic unity. The proponents of Euroatlantism consider the EU as one of the pillar of the Euroatlantic security community, which requires significant strengthening ${ }^{84}$.

The Euroatlantists incite the deeper integration of the EU in foreign and defence policies and they are not afraid of turning the EU into a federation or confederation, since there are fuses guaranteeing the pro-Atlantist politics of such Euro$\mathrm{pe}^{85}$. According to the euro-Atlantists, federal pro-Atlantist Europe could be very useful in advocating the values of Euroatlantic community through the Greater Middle East and CIS countries. United Europe could also limit the tendencies of the US unilateralism through international institutions in a more effective manner at the same time maintaining the transatlantic relations and the Euroatlantic community ${ }^{86}$. The Euroatlantists suggest implementing the strategy of the institutional bounding towards the US.

The Eurocontinentalist and Euroatlantist approaches towards further integration of the EU are the same, but the motives for federalisation differ significantly. For the Eurocontinentalists, federalised Europe is the value itself. Their long-term interest is not the preservation of the transatlantic community, but the strategic independence of Europe. The federal structure of the EU and the formation of the area of the EU's specific interests are the guarantees of the independent future of Europe ${ }^{87}$.

The only possibility for the emergence of the EU as the united geopolitical subject is through political, cultural and social consolidation of European continental "core", which consists of Germany, France, the Benelux countries, and Austria, according to the Eurocontinentalists. In other words, "geopolitical Europe" could be formed only through the neutralisation of influence of the pro-transatlantic EU member states on the EU integration process or by altering their geopolitical orientation.

\footnotetext{
${ }^{83}$ The Atlantic Council of the United States, "Permanent Alliance? NATO's Prague Summit and Beyond", Policy paper, April 2001; Patten Ch., "A Security Strategy for Europe", Oxford Journal on Good Governance, 1, 1, 2004, p. 13-16; Ash T.G., Free World: Why a Crisis of the West Reveals the Opportunity of Our Time, London: Allen Lane, 2004.

${ }^{84}$ Schmidt P., Geipel G.," Forward Again in US-European Relations", Oxford Journal on Good Governance, 1, 1, 2004, p.29-32.

${ }^{85}$ Ash T.G., Free World: Why a Crisis of the West Reveals the Opportunity of Our Time, London: Allen Lane, 2004.

${ }^{86}$ Ibidem; The Atlantic Council of the United States, The Centre for European Reform, and The Institute for the U.S. and Canadian Studies at the Russian Academy of Sciences, "The Twain Shall Meet: The Prospects for Russia-West Relations", Policy paper, May 2002, http://www.cer.org.uk, 14092004.

${ }^{87}$ Emerson M., "The Wider Europe as the European union's Friendly Monroe Doctrine", CEPS Policy Brief 27, Centre for European Policy Studies, October 2003, http://www.ceps.be, 2710 2002.
} 
Independent Europe could emerge only through its clear geographical and institutional self-definition and for achieving this it should dissociate from the US at first ${ }^{88}$. The Eurocontinentalists realise that the EU would not be able to become the influential power of the world, if it continues to expand infinitively. Europe must structure the space around itself through the common and effective foreign policy in order to achieve the status of global power.

The clearest examples of implementing the directed geostrategic politics towards Eurasia are the EU initiatives of "Wider Europe" and "The New Neighbourhood". Communication from European Commission "Wider Europe - Neighbourhood: A New Framework for Relations with our Eastern and Southern Neighbours" shapes the guidelines and perspective of the EU relations with Russia, Byelorussia, the Ukraine, Moldova and South Mediterranean states, which include Algeria, Egypt, Israel, Jordan, Liban, Libya, Morocco, the Palestinian Autonomy, Syria and Tuni$\mathrm{sia}^{89}$. The Communication could be considered an aim to shape the new integrated "Neighbourhood Policy", which would allow establishing the framework of friendly relationships and the stability zone around the borders of the EU. The articulation of the common interests of the EU and its neighbours is attempted in the document. Those interests would be the stimulation of the balanced development and trade together with the propagation of democratic values and the legal system of EU. The geopolitical evaluation of such politics would suggest that EU attempts to form the ring of the buffer states around its borders.

The politics of Wider Europe and New Neighbourhood is rather moderate and limited instruments of EU geopolitics. The Eurocontinentalist projects of the development of Wider Europe and New Neighbourhood are much more interesting. The recent study on Wider Europe by the Centre for European Policy Studies $(\mathrm{CEPS})^{90}$, which is one of the influential think-tanks of the EU, draws the borders of the zone of EU's vital interests in Eurasia, which is called Pan-Europe (Greater Europe) and also postulates the institutional mechanisms of the Eurocontinentalist geopolitical reformation of Eurasia ${ }^{91}$.

The Pan-Europe is the potential sphere of influence of the EU and consists of the three geopolitically important areas: 1) the territory of the EU, 2) Wider Europe, 3) European Neighbourhood, and these areas are the sphere of the vital interests of the EU, according to the CEPS study. The study suggests that the EU territory consists of the territories of the member states, including Bulgaria, Romania and Croa-

\footnotetext{
${ }^{88}$ Guessgen F., It fires back! The Impact of the European Union's Common Foreign and Security Policy (CFSP) on the Evolution of a European identity, In European Political-economy Infrastructure Consortium (EPIC): Ionian Conference 2000 - Challenges of the New Millenium, Corfu, 20-22 May, 2000: Theme: Governance and citizenship in the European Union - the influence of culture, pages 20, Corfu, Greece, http://aei.pitt.edu/archive/00000642/01/ICGuessgen.pdf

${ }^{89}$ Commission of the European Communities, Communication from the Commission to the Council and the European Parliament "Wider Europe-Neighbourhood: A New Framework for Relations with our Eastern and Southern Neighbours", Brussels: 1103 2003, COM (2003) 104.

${ }^{90}$ Further see Centre for European Policy Studies, http://www.ceps.be

${ }^{91}$ Emerson M., "The Shaping of a Policy Framework for the Wider Europe", CEPS Policy Brief 39,

Centre for European Policy Studies, October 2003, http://www.ceps.be, 2310 2003; also Emerson

M., (note 87).
} 
tia, which are supposed to join the EU in the nearest future. Wider Europe consists of the states, which identify themselves with European history, culture and civilisation at the sufficient level. Those countries are the current non-Western members of European Council from the CIS. The European Neighbourhood includes the Middle East (the boundary of this region is the Eastern borders of Afghanistan ant Pakistan) and Central Asia. In other words, the Greater Middle East also belongs to the European Neighbourhood $^{92}$.

The possible instruments of EU geostrategic politics, i.e. the institutional mechanisms connecting those three areas of potential Pan-Europe are proposed in the CEPS project of the construction of Pan-Europe. The EU should stimulate the processes of the Europeanisation in the area of Wider Europe. The Europeanisation is understood here as the impact of the European integration on the countries of the area of Wider Europe and the adaptation of these states to the EU. The Europeanisation is considered as the process of the synchronisation and harmonisation of internal and foreign policies of Wider European states with the EU ones. The Europeanisation of Wider Europe should consist of: 1) the adaptation of business conditions to the norms of the EU and the democratisation of the political system, 2) implementation of the obligations in the sphere of the human rights, 3) the promulgation of European values, beliefs ant identity ${ }^{93}$.

The EU should shape the four common areas of the EU and Russia (the economic, the internal security, the external security and the cultural-educational ones), which are anticipated in The Communication for the EU and Russia's Partnership and Cooperation more actively and systematically as suggested by the study. The establishment of the institutional Pan-European mechanisms for co-ordination of policies and the resolution of disagreements are also very important, according to the study. The study proposes to establish the "Pan-European Conference" which would operate under the direction of the EU (it's future minister for foreign affairs), Russia and the Co-ordination group of the two rotating non-EU states ${ }^{94}$. Generally speaking, the study could be taken as the project of the establishment of bipolar PanEuropean geopolitical bloc in western and central Eurasia.

The Europeanisation of Wider Europe should be the goals of the common European geostrategic policy in the short-term and mid-term period. However, the main condition of the successful establishment of Wider Europe is deeper integration (federalisation) of the EU through the mechanisms of enhanced and closer cooperation, which would allow to finish the scheduled enlargement to a Balkans and, eventually, Turkey ${ }^{95}$. The other states of Wider Europe, excluding Russia, could expect joining the EU after the successful completion of Europeanisation.

${ }^{92}$ Emerson M., (note 91).

${ }^{93}$ Ibidem.

${ }^{94}$ Emerson M., Institutionalising The Wider Europe, CEPS Policy Brief 42, Centre for European Policy Studies, October 2003, http://www.ceps.be, 23102003.

${ }^{95}$ Emerson M., Tocci N., "Turkey as a Bridgehead and Spearhead. Integrating EU and Turkish Foreign Policy", EU-Turkey Working Papers, Centre for European Policy Studies, 1, 2004, http:// www.ceps.be, 29102004. 


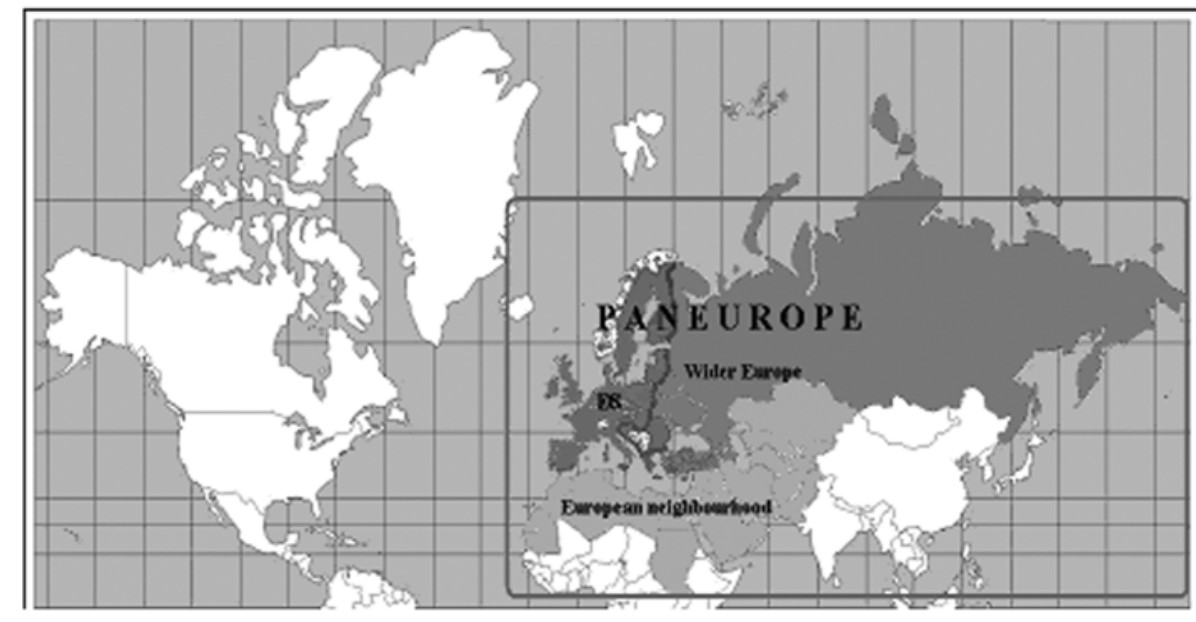

- - Eastern border of the EU 2005

Map 3. CEPS Paneuropean project

In the case of "European Neighbourhood" the relations have the different nature, according to the study. The similar net of the crosscutting common institutions dominated by the EU and Russia, which probably would emerge in Wider Europe $^{96}$, is less possible in the "European Neighbourhood" (the Greater Middle East) because the interests of not only of the EU and Russia but also the interests of US will clash there. The author of the Pan-European project suggests the more cautious politics towards the Greater Middle East and it could be just the activation of Barcelona process and the support to the projects of the democratisation and the economical reform in the countries in this region expecting that it would eventually form the preconditions and need for Europeanisation in the long-term. These expectations are based on the presumption that the implementation of significant social and political reforms in the European Neighbourhood countries would automatically lead them to the Europeanisation, since the EU geographical proximity and its economic thrust would naturally direct to such processes ${ }^{97}$.

However, it is hard to say to what extent the Pan-European project reflects the position of the governing elites of the European continental states. The European public opinion supports the establishment of the European super-state as indicated by public opinion surveys ${ }^{98}$. The CEPS project is a fairly rational geopolitical program. The project proposes the establishing the EU's interest zone and ousting the hegemonic power (the US) from it by bufferisation and bounding of Russia, the

\footnotetext{
${ }^{96}$ Emerson M., (note 17).

${ }^{97}$ Emerson M., (note 91).

${ }^{98}$ It is not surprising that 83 per cent respondents agree on that the EU should be equal by its power to the US in France, but 50 per cent of respondents share the same opinion in Poland and the United Kingdom as well, see “A European Superpower", The Economist, November 13-19, 2004, p. 38.
} 
regions of CIS and the Middle East through institutional framework. Such politics allow assuring the fairly large buffer zone for its security and diversification of the supply of energy resources. Pan-Europe could successfully claim the control all over Eurasia and challenge the USA globally ${ }^{99}$. It would be something like Europocentric Eurasism. This project, undoubtedly, is the academic projection of long-term Eurocontinentalist strategy.

\subsection{China's Geopolitical Strategy}

China has chosen the politics of co-operation and tolerates the global hegemony of the US until this does not interfere in China's internal affairs. This choice is rational, since China's military forces are weak, despite rapid economic development ${ }^{100}$. China aims to hide its aspirations for the domination in East and Southeast Asia and to gain economic benefits through this co-operation. The US and other Western states' investments are essential for the economic development of China. The economic gains achieved through this kind of foreign policy could be used for the further modernisation of the Chinese army and for the achievement of China's long-term interest, which is the domination in East and Southeast Asia.

The resolution of disputes with neighbouring states, successful integration in the global economy, strengthening the economic relations with the other East Asian countries, the peaceful enhancement of influence in East Asia and establishing itself as unquestionable dominating power in the region is the main mid-term goal of China ${ }^{101}$. It seems that the Chinese vision of the region's future is very different from its current structure. China aims to eliminate the bilateral alliances, which are considered as a legacy of the Cold War and to establish the structure of multilateral security with ASEAN countries based on their mutual trust and benefit and the coordination of actions ${ }^{102}$. China faces the concurrence of India and Japan and the hostile influence of the US in East Asia ${ }^{103}$. Chinese strategic thinkers also point out the necessity for the establishment of survival space around China, that means turning its neighbour states into buffer ones and taking control over the South China Sea and East China Sea ${ }^{104}$. China may be planning to create the system of regional security and co-operation without the US in East and South East Asia and to ouster the Americans from this region (the bufferisation tactics) in the mid-term period.

\footnotetext{
${ }^{99}$ If the area of potential Pan-Europe would be united its population would be 1.2 billion and its total GDP would be 10.3 trillion USD in 2001.

${ }^{100}$ Paltiel, J.T., "Debating Hegemony in Asia", Heartland limes, 2001, 3, p. 115-121.

${ }^{101}$ Lai D., Learning from the Stones: A GO Approach to Mastering China's Strategic Concept, SHI, Strategic Studies Institute, http:// www.carlisle.army.mil/ssi/, 14052004.

${ }^{102}$ Glosserman B., "China's influence soars in Asia", The Japan Times, 200405 17, http:// 202.221.217.59/print/opinion/eu2004/eu20040517bg.htm, 17052004.

${ }^{103}$ Umbach F., "ASEAN and Major Powers: Japan and China - A Changing Balance of Power", Weltpolitik.net, http://www.weltpolitik.net/texte/asien/asean.pdf 04112004.

${ }^{104}$ Johnson A. I., Realism(s) and Chinese Security Policy in the Post-Cold War Period, in Kapstein E.B., Mastanduno M., Unipolar politics: Realism and state strategies after the Cold War, New York: Columbia University Press, 1999, p. 261-318.
} 
It seems that China aspires to become the super-power equal to the US in the long-term perspective. These ambitions incite its active involvement in the global politics. China cannot penetrate into the regions dominated by the West and Western companies, so it is spreading its influence to the regions, which are in the geopolitical periphery like Africa or Latin America and where the hostility to it is insignificant. However, the probability that China will try to challenge the existing world order remains low at least for the next 30 years. China has neither sufficient military capabilities to act globally, nor suitable ideology to justify its global ambitions. Any aggressive actions of China would face the hostile response of the US in any region of the world ${ }^{105}$. China fears its Westernisation or division by the US in order to prevent it from achieving the status of super-power ${ }^{106}$. Therefore, the global anti-American politics of China is hardly imaginable.

China is likely to combine the strategies of alignment and institutional containment in the short-term. It would try to oust the Americans from East and Southeast Asia and establish its influence in other continents in the mid-term, so creating the possibilities for forming the global anti-American alliances in the long-term.

\subsection{The Problems and Challenges of Geopolitical Development in the Long-Term}

The main feature of the current international system is its unipolarity with the US as unquestionable hegemonic power. The most interesting question about the future of the international system is whether the US would be capable of preserving and strengthening the unipolarity or the system will move towards the bipolar or multipolar one. The current unipolarity of the international system is fairly unique in the historical perspective, since the long-lasting dominance in the international system has been achieved only by the empires (the Roman Empire, the Empire of Charlemagne, France under Napoleon and the British Empire) up to 20th century. The US became the leader by demonstrating its influence based on the military, political and economic power but without creating the empire up to now.

According to the neo-realist theory, which concentrates on the structure and changes in the international system, the unipolarity is the most unstable form of the international system. One of the main principles of the neorealist theory is the tendency of the international system towards the balance of power. Therefore, the shift of the unipolar international system towards some configuration of the balance of power (bipolar or multipolar one) or towards the global empire is only a question of time. On the other hand, nobody could say how long the domination of one hegemonic power could proceed.

\footnotetext{
${ }^{105}$ National Intelligence Council, NIC 2020 Project, "Asian Responses to the United States", Discussion paper, 2411 2003, http://www.cia.gov/nic/PDF_GIF_2020_Support/2003_11_24_papers/ikenberry_asia.pdf, 24102004.

${ }^{106}$ Johnson A.I., (note 104) p. 261-318.
} 
Some of the political scientists presume that the international system is based on the balance of threats instead of the balance of power ${ }^{107}$ and if other actors of the international system do not consider the hegemonic power as threat, then the hegemony may be long lasting, because other states do not intend to limit it in this case. If there is no fear of the transformation of hegemonic power to the power limiting the sovereignty of other participants of the international system, then there is no rational reason for hostility towards it.

One could foresee two processes in the global geopolitical development in long-term perspective according to the approaches mentioned above:

- the US will try to preserve the unipolar international system and strengthen its hegemonic status by preventing any other state to achieve the approximate power or form a coalition against the US in Eurasia

- the other geopolitical actors would try to establish the zones of their exceptional interests in Eurasia and/or the systems balancing the power or threat of the US

During the time, conditions may form, which will allow changing the unipolarity by limiting the relative superiority of the US or by transforming it qualitatively together with the international system in the long-term (until 2035).

The second important factor is the evolution of the status of Europe as a geopolitical entity in the long-term perspective. Currently the EU is an atypical geopolitical subject, because it is still formed by the interests of the member states and their compatibility. Therefore, the transformation possibilities of the EU are a very important issue of the further evolution of the international system. Would Europe become one of the participants in international system, or would it remain the conglomerate of national states with their own interests and identities? The transformation of the EU may be decisive step in the transformation of all international system. If Europe became the single geopolitical subject, it could be potentially the main actor limiting the hegemony of the US. The fall of the priority of the national sovereignty and national interests in Europe would signalise the change in the structure of international anarchy, which is one of the main features of the international system. The international system would become the arena of the interactions among international structures and regional units instead of the national states.

The main challenge to foreign policy of Lithuania would be facing a difficult choice: should Lithuania support the strengthening of the global hegemony of the US and the irreversible establishment of the American global power or should it support the possible aims of the European core states in order to weaken the transatlantic ties and create the counter-alliance for balancing the hegemony of the US (if such a dilemma would ever emerge)?

${ }^{107}$ Walt S. M., "Alliance Formation and the Balance of World Power", International Security, 9, 4, 1985, p. 3-24. 


\section{The Opportunities for Lithuania's Foreign Policy}

Every country (or the group of countries) has a unique geopolitical code, which is formed and constructed in the interaction process with other geopolitical actors and the geopolitical environment. The changes in the global geopolitical space (environment) are usually related with the changes in the geostrategic goals of the main geopolitical actors or the changes in their means for achieving those goals. These changes create pressure to other geopolitical subjects, because they should modify or reconstruct their current geopolitical schemes radically in order to adapt themselves to the international environment that has changed. The states aim either to reconstruct the international system, so that new processes would always increase their relative (and structural) power or to preserve stability of the international system in order to prevent the enhancement of the relative (and structural) power of another geopolitical subject.

Every state tries to enhance its own relative and structural power and every geopolitical scheme is projected by a state for the achievement of that purpose. These dimensions of power can guarantee the capability of the state to control the processes of interaction with other states and set the rules and the procedures of making decisions in the international relations. The power allows the state to achieve space for geopolitical manoeuvres and avoid the dependence on other geopolitical actors.

Therefore, every important geopolitical subject projects a few alternative geostrategies. They are used to providing the conditions for the realisation of the goals mentioned above. The geostrategic alternatives projected by the great powers are forming the eventual and global geopolitical scenarios. There are a several scenarios about the development of relations among the US, the European Union and Russia. These scenarios are shaped by the interaction process of the geostrategic triangle of the three states mentioned above and these scenarios are:

- the transcontinental alliance (US-EU-Russia axis)

- the isolation of Europe (US-Russia axis vs. Europe)

- the Eurocontinentalist alliance (EU-Russia axis vs. the US)

- the Euroatlantist alliance (the US-EU axis vs. Russia)

\subsection{The Importance of the Global Geopolitical Code to Lithuania's Geopolitical Code}

The interaction of the states of the geostrategic triangle consisting of the US, the EU and Russia determines the transformation opportunities of all Eurasian geopolitical space. Various scenarios of transformation of this space would unavoidably have the direct influence on the status and perspectives of Lithuania as a geopolitical subject. The factor of another geopolitical subject (e.g. China) is important to Lithuania only as much as their geostrategic choices affect the global and regional geopolitical codes of the US, the EU and Russia and, therefore, change the interactions this triangle as well. 
In order to identify the optimal geopolitical code of Lithuania and evaluate the opportunities of Lithuania's foreign policy a researcher should:

- to examine the opportunities of geopolitical subjects, which are in the geostrategic triangle of the US, the EU and Russia to act in the global geopolitical environment

- to identify the place of Lithuania in the eventual scenarios of transformation of relations between the members of the triangle bearing in mind that the geopolitical status and the opportunities of Lithuania's foreign policy directly depends on the changes in the global and regional geopolitical situation

- to distinguish and examine the components or measures of the power used by the US, the EU and Russia towards Lithuania and other Central and Eastern European countries and identify the spheres and directions where Lithuania could influence the geostrategic choices of the US, the EU and Russia on this basis;

- to define the vectors of Lithuanian foreign policy allowing not only to implement successfully the specific functions of international politics requested by the main geopolitical actors in their strategic plans, but also to acquire means for the effective influence on the interrelation scenarios among the US, Russia and the EU;

- to identify the directions of Lithuanian foreign policy, which would be helpful in neutralising the aspects of conjuncture of the global geopolitical dynamics and allowing to accept the role of the formative geopolitical subject in the regional environment.

\subsection{The Importance of Relative and Structural Power in Lithuania's Geopolitical Code}

Lithuania, in fact, like other Baltic States belongs to the conjunctive geopolitical subregion, which emerged as a result of the clash of opposite geopolitical powers ${ }^{108}$. The Lithuanian geopolitical anomalism (the depositary nature of the state's independence) increases the dependence of the state on the power balancing games of the great powers. Therefore, the geopolitical code of Lithuania should be orientated towards the strategy of the neutralisation of the negative consequences generated by possible geopolitical manipulations of the global geopolitical actors. The process of strengthening the relative and structural power of the state is the base of this strategy.

The relative power could be understood as the potential of the state or as the capability to control the results of the interaction with other states. The relative power of the state is the entirety of its various resources (military, economic, social, political and cultural ones) $)^{109}$.

The structural power characterizes the capability of the state to set the rules of international relations, its agenda and the rules of decision-making.

Lithuania is seeking to strengthen its structural power by the integration into the structures dominated by the hegemonic power (the US) - NATO and the states of geo-economic core (OECD) - the EU. However, the structural power is not only the participation, but also the opportunity to balance in those institutions and, therefore, it implicates the necessity of forming geopolitical alliances.

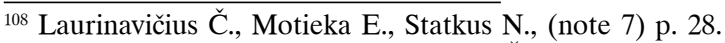

${ }^{109}$ Statkus N., Motieka E., Laurinavičius Č., (note 2) p. 84. 
The criteria of the effectiveness of the alliance should be not the capability to implement successfully the specific functions of international politics ascribed to Lithuania in the geostrategic plans of the main geopolitical actors, but the capability to achieve means allowing to influence the geopolitical codes of the main superpowers or the scenarios of the dynamics of the global geopolitical codes effectively.

The participation of Lithuania in the international organizations or geopolitical alliances can not presuppose the enhancement of its structural power, because of the lack of significant relative power while this vacuum is filled by the relative power of other states. In fact, this situation eventually reduces the general power of the state and its independence. The Lithuanian structural power could be strengthened only by acquiring sufficient relative power in a certain sphere like dynamic economics, effective international mediation, analytical capabilities, and importance to the transportation and so on. Lithuania could influence the behaviour of relatively more powerful states only by achieving the advantage of structural power in a certain spheres ${ }^{110}$.

\subsection{The Eventual Geopolitical Functions of Lithuania}

Lithuania's integration into Euroatlantic security structures provides two alternatives. The first one is to become the outpost for maritime powers and the second one is eventual transformation into a geopolitical link ${ }^{111}$, which could stimulate the democratisation and the geopolitical orientation towards Euroatlantic powers of countries of Eastern Europe (the Ukraine, Byelorussia) and mediate their relations with the security structures of the West. The historical relations with the Ukraine and Byelorussia and the common experience in the Soviet Union provide the opportunities for Lithuania's active involvement in Eastern European political processes. Lithuania should reach a qualitatively new strategic partnership with Poland in order to enhance the opportunities of becoming the outpost of transatlantic security structures in Eastern Europe and striving to become one of the leading countries in the Central and Eastern Europe. The new strategic partnership with Poland would guaranty closer relations with the US, create the preconditions for the role of the link between Northern and Southern Europe and enhance the structural power of Lithuania. The enhancement of the structural power would allow influencing the processes in the EU more effectively.

The perspectives of Lithuania's geopolitical status may be corrected by increased co-operation between the American and Russian governments and the formation of a transcontinental security system led by the US. Lithuania is the member of NATO and this would suggest the outpost role for Lithuania in the dimension of the "hard" power, but the occurrence of increased co-operation between the US and Russia may alter the geopolitical evolution of Lithuania radically.

The emergence of the transcontinental security system in the 21st century may condition two opposite scenarios of the development of Lithuanian geopolitical situation. Lithuania may turn back to the status of "exchange object" and fall into the redistribution process of in the spheres of influence between Russia and the US or

${ }^{110}$ Ibidem, p. 87. 
between the EU and Russia according to the first scenario. On the other hand, Lithuania may acquire the status of the link between the West and the East and become the geopolitical connection by exercising the function of instrument for the enhancement of the political and economic influence of the US on Russia in its geostrategy.

The probability of Lithuania's transformation into the link-state would increase in case of Westernisation of Russia. The Atlantistic dimension would dominate in the geopolitical code of Westernised Russia, the neoeurasism would be neutralized and the relations between Russia and the West would rise into another level. Practically, Russia would be incorporated successfully into the transatlantic space. The role of the bridge state would incite the enhancement of relative power (e.g. by performing the function of international mediator) of Lithuania and, therefore, the structural power as well. The status of the linkstate would also reduce the dependence of Lithuania on the balancing games of great powers, therefore, minimizing the depositary nature of Lithuania's independence.

The participation in NATO does not guarantee the enhancement of structural power for Lithuania in case of the new global structures of security of different character are formed between the US and Russia (which could only mask its neoeurasist geopolitical code). The geopolitical perspectives of Lithuania (despite the legal guarantees after joining NATO) would depend on its balancing abilities among the great powers and on their interests in Central and Eastern Europe.

Lithuania should form the effective mechanism of the regional balancing, which could neutralise the negative effects of the possible change in a global geopolitical situation for the national security. This mechanism would probably allow avoiding the restoration of Lithuania's status as that of the "exchange object".

The evaluation of these alternatives according the criteria of the preservation of a relative political autonomy of the state implicates the conclusion that the restoration of the status that of "exchange object" is essentially dangerous to Lithuania, because it leads to its remaining in periphery. This danger could be avoided by influencing the geopolitical codes of the great powers in order to achieve the function of the bridge or barrier in them. Lithuania should perform these functions actively ${ }^{112}$.

\subsubsection{Lithuania's Place in the Geostrategy of the US}

The place of Lithuania in the geostrategy of the US depends on both the priorities of foreign policy of the US administration and on the development of the global geopolitical situation, especially the dynamics of the interrelations of the US, the EU and Russia.

The US would like to turn the Baltic States into the geopolitical link (bridge) for its economic and political expansion towards Russia, Byelorussia and the Ukraine. The US designs the Baltic States as the outpost or the wedge of influence separating the countries of Western Europe from Russia and, together with other countries of Eastern Europe as the agents of its influence in the EU in case Russia shifts from its pragmatic pro-Western geopolitical code to the Eurocontinentalist or Eurasist one or the first strategy did not work ${ }^{113}$.

${ }^{111}$ Lopata R., "Etapas ịveiktas, priešaky - naujos paieškos." Lietuvos Rytas, April 23, 2003.

${ }^{112}$ Laurinavičius Č., Motieka E., Statkus N., (note 7) p. 193.

${ }^{113}$ Ibidem, p. 184. 
If the EU turns away from the US and became its rival, the US would likely seek to establish Lithuania as its outpost performing the function of "security fuse" in the US geostrategy by assisting to keep the power balance in Europe and assuring that the European states would remain dependent on the US security guarantees.

Lithuania should co-operate with the US in transforming Russia into a democratic country or forming a barrier to the Russian expansion towards Central and Eastern Europe (and eventually to Western Europe) in case Russia fails to democratise. Lithuania should also oppose further federalisation of the EU, the acceptance of the model of "different speeds" in European integration and the formation of military dimension of the EU or regional security initiatives eliminating the US. Such politics would allow strengthening the status of Lithuania in the US's geostrategy in the short-term.

\subsubsection{Lithuania's Place in Russia's Geostrategy}

The changes in the relations between Russia and the US after September 11 (the establishment of the NATO-Russia Council) and the endeavour of Washington in forming the transcontinental security zone have provided space for Russia's geostrategic manoeuvres.

Russia is seeking to weaken the structural power of the states in Central and Eastern Europe (including Lithuania) by balancing between the US and the EU and initiating the establishment of the new structures of global security or altering the character of the established ones (e.g. the security alliance based on the G-8, or the multilevel NATO) so that they provide the means allowing to influence the decision-making process in the main security issues after the recent round of NATO's enlargement.

Moscow projects the strategy of the alternative infrastructure of transit in developing co-operation with the EU and the US in energy sector. This strategy is directed towards the exclusion of the Baltic States from the projected system of transit, therefore, reducing the opportunities for Lithuania to become a geopolitical bridge-state.

On the other hand, Russia is seeking to transform the Baltic States, or at least one of them, to the "agents of influence" in the transatlantic and European institutions of the West using the vulnerability of Lithuania and other Baltic States in terms of economic and energy supply dependence on Russia. Lithuania's total dependence on Russia in the energy sector allows the possibility of becoming nothing more than Russian "terminal".

Russia is seeking the direct dominance in the energy sector of Lithuania by controlling strategically important objects of Lithuanian energy system. This kind of dominance would eventually lead to the integration of Lithuania and other countries of Central and Eastern Europe to the Russian energy system and the dependence on it. This dependence would allow Russia to turn Central and Eastern Europe into geopolitical buffer against the US and the Atlantistic countries of Western Europe ${ }^{114}$.

\footnotetext{
$\overline{{ }^{114} \text { Statkus N., Motieka E., (note 12) p. } 27 .}$
} 


\subsubsection{The Place of Lithuania in the Geostrategies of the Continental} States of the EU

Lithuania (like other the Baltic States) remains the mean (the object of exchange) in the strategies of Germany and France and these countries are using this mean when implementing their foreign policy towards Russia. The main attitude of these countries is not to harm their relations with Russia on the issue of the Baltic States.

The position of both Germany and France towards the Baltic States depend on the constellation of power in the Western institutions. This principle of the politics of Germany and France would become especially important to Lithuania in case of the systemic break up in the Euroatlantic space and the consonance of the EU and Russia (which could be the possible reason of this break up) on the grounds of Eurocontinentalism as its consequence. This would be the serious threat to both Euroatlantism and the independence of the Baltic States, since both France and Germany would try to bargain with Russia ignoring the interests of these states and in absentia of them. The Lithuania's role could be various ranging from the "customs of the EU" to the Russia's province de facto in this context.

Therefore, Lithuania would become the province of the EU having no guarantees of security and drifting to the sphere of Russia's influence despite of staying in the EU formally in the case it had chosen the EU side in its possible confrontation with the US. The EU would not be capable to induce Russia to democratisation and would shift to the politics of the balancing towards it. The function of Lithuania of that geopolitical link for democratising the East would become irrelevant in this case ${ }^{115}$.

\section{Opportunities for Lithuania in the Context of Interaction of the Geopolitical Codes}

Lithuania may acquire various functions in uniting or separating Russia (the main continental power) with the EU and the US, because of its location between the states of Eurasian coasts and the continental "heart". It is important to take this fact into consideration when discussing the possible scenarios of the interaction of the global geopolitical codes and Lithuania's place in them.

\subsection{Opportunities for Lithuania in the Transcontinental Alliance (US-Russia-EU Axis)}

The scenario of the transcontinental alliance would mean the formation of the alliance of the co-operation and the multilateral support among three main geopolitical actors - Russia, the US and Europe. This security system projected by the US and based on the close co-operation between NATO and Russia would join the geostrategic triangles of the US-Russia-EU and the US-China-Japan ${ }^{116}$ providing the favourite opportunities to the transformation of Russia into the main ally of the America in Eurasia potentially able to balance the power of the EU and to become a counterweight to the geopolitical projections of China.

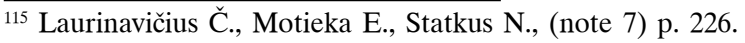

${ }^{116}$ Brzezinski Z., (note 34) p. 68.
} 
The US is likely to form the transcontinental alliance by adapting the established security structures and NATO in particular. The reformed NATO should become the axis of the transcontinental security system ${ }^{117}$. The US would legitimise its actions, consolidate its control on another states and preserve its initiative in the planned system if the formation of the transcontinental alliance implemented through the reform of NATO so the America were interested in it.

The clash of the geostategic interests of the US, Russia and the EU disappears (or delays) in the case of the implementation of this scenario and the mediators had become unnecessary, because the US, Russia ant the EU had solve their external problems by dealing directly. The region of Eastern and Central Europe, including Lithuania, would become a relatively stable zone requiring a little attention. Therefore, the establishment of the transcontinental alliance could be favourable to Lithuania in becoming a "golden province".

However, another scenario of the configuration of power is possible in this geopolitical context too. Russia could use its membership in the transcontinental alliance and the status of the main ally of the US in Eurasia for achieving its long-term strategic plans, i.e. divide Europe into the influence spheres of the US and itself, achieve the freedom of manoeuvre in the post-Soviet space (the facade transcontinentalism) and transform NATO into multilevel organisation with significant its influence on it. In this case the membership of Central and Eastern European countries, including Lithuania, have unavoidably become a formality. The conditions were set for turning back Lithuania to the status of "exchange object" and into "grey zone" of security.

The strategic alliance with powerful ally in Central Europe and active regional politics in order to form the mechanism of the "containment" of Russia's power spread and geopolitical manipulations would be helpful in avoiding this geopolitical perspective.

\subsection{Opportunities for Lithuania in the Case of the Isolation of Europe (US-Russia Alliance vs. the EU)}

The reason for this scenario might be the combination of both Russia's aim to achieve the freedom for geopolitical manoeuvres and strengthening its influence on European system of security and the interest of the US in limiting European power. Both Russia and the US may seek exploit Central and Eastern European states as their agents inside the EU in this context. The US would be interested doing this in order to slow down the federalisation of the EU and drive a wedge between Russia and Europe. Russia would seek this in order to enhance its influence on Europe and dismantle the Euroatlantic security structures as well.

If the America itself had become interested in the Russia's involvement into European security system in order to balance the power of the main states of the EU as that of consequence of their growing confrontation with the US, the situation of Lithuania would become critical. The US would be interested in maintaining the then power configuration and Russia would seek to restore its influence on Central

${ }^{117}$ Ibidem, p.71. 
and Eastern Europe through geopolitical manipulations and participation in the mechanism of the balancing the power of Europe and supported by the US in this case.

The great powers of Western Europe were likely tried enhance their influence on Central and Eastern Europe in order of breaking the isolation in the case of this scenario, but they would face the domination of the US in military and political sectors and Russia's in energy one in this region et cetera paribus. The aims of the geopolitical great powers to establish or enhance their influence on this area may turn the region in the "shatter-belt zone" which automatically presuppose instability in the countries composing it.

Lithuania should seek to reduce the isolation of Europe by searching and exposing the commons in the strategic interests of both the US and the EU in this context.

\subsection{Opportunities for Lithuania in the Case of Eurocontinentalist Scenario (Russia-EU Axis)}

The preconditions of eurocontinentalist scenario may be unavoidable multilateral economic dependence between Russia (on the European investments) and the $\mathrm{EU}$ (on the energy resources) and the interest of both Russian government and continental states of Europe in limiting the unilateralist tendencies of the US in global politics.

The politics of the US towards Europe may be the indirect impulse for this scenario in the case of its neo-conservative foreign policy. This policy consists of political divide of the EU, pressure on the main Western European states, unilateral actions weakening the tendency towards international institutionalism and the instruments of collective security and it may cause the return to the politics of balancing in Europe and the tendencies towards enhancing anarchy in the international system.

This would mean the turning point of the Euroatlantic system and would form the favourable environment for Russia's diplomacy and geopolitical manoeuvres. The main states of the EU would set their priority on the convergence with Russia in order to balance the enhancing power of the US in the European security system as the reaction to the American neo-conservative foreign policy. Russia would seek form a balance of power of a new character by using the frictions in Euroatlantic space in order to eliminate the influence of the US on Europe.

The Eurocontinentalist scenario would provide many possibilities for the status and functions of Lithuania. The optimal scenario would be Lithuania's transformation into the active and relevant bridge-builder easing the co-operation and guaranteeing the economic transit between the EU and Russia in this context. However, it would be rather hard for Lithuania to play a role of "the bridge" alone without loss of its autonomy in a broad sense. Therefore, Lithuania should protect its interests by co-operating with powerful ally in Central and Eastern Europe, which could help it in the amortisation of negative consequences of the convergence of Russia and the EU.

The space between Russia and West Europe may be divided into spheres of influence (geographical or sectoral ones) in the case of Eurocontinentalist scenario. Lithuania would become the province either of Russia or the EU. The gravitation of 
Lithuania towards one or another centre of power would depend on the level of its integration into the structures of the EU. Lithuania's success in joining the economic core of the EU and performing functions useful to the main states of it would strengthen its role in the geostrategic plans of Germany and France and make the possibility to avoid the status of Russia's geopolitical province more viable.

On the other hand, the US would try to weaken and divide the developing continental block. Therefore, the US would strengthen further its influence on Central and Eastern Europe where it has a fairly significant political influence. Lithuania potentially might become the instrument of the US, i.e. the "wedge" dividing Western Europe from Russia.

Summarising, Lithuania (and other countries of Central and Eastern Europe) would turn into the "grey zone" of security with permanent tension of the dependence and threat of the possible pacts between Russia and the main states of the EU in case it remain the clash-zone of the interests of the two geopolitical actors (Russia and the EU). Therefore, the third vector (the US) is that of vital importance to the Lithuania and other countries in Central and Eastern Europe, because it would allow them balance the power spread of the axis of European continental states and Russia and provide some more freedom of the manoeuvre.

\subsection{Opportunities for Lithuania in the Case of Eurasism vs. Euro-atlantism (US-EU Axis) Scenario}

If Russia refused to integrate into Euroatlantic space and transforms its current pragmatic and pro-Western geopolitical code into neo-Eurasist one and as consequence of it tries to restore domination in the post-Soviet space and another regions of Eurasia and the US and great powers of the EU react adequately to these changes the colder relations between it and the West would form and the conflict of the conception of Euroatlantism with the new Eurasist geopolitical code of Russia would emerge.

Russia's aims turning the Baltic region into neutral zone or its sphere of influence, i.e. the barrier separating it from the Euroatlantist allies may be the premise of the growth of the Eurasism. It should be noted that the possibilities of the realisation of the Eurasism depend on Russia's abilities to prepare the favourable environment for it. This would happen only in the case of rivalry relations between the US and the EU. Lithuania might become the forgotten and irrelevant European periphery and the easy prey for Russia then. This rivalry would turn back the most of Central and Eastern European countries to the "grey zone" of security, similar of that existed in the beginning of the last decade of the 20th century.

On the other hand, the West can try to establish the system of outposts around Russia providing the economic (the EU) and military-political (the US) support for the countries performing these functions in the case of the unity of the EU and the US on containing Russia. Lithuania is a likely outpost of the US or (and) Europe in the East, because of its membership in the security structures of the West. This scenario would increase the role of Lithuania in the geostrategic plans of the US ant the EU ant it could establish itself as the state performing the significant function in the Euroatlantic space. 


\section{The Partial Neutralisation of the Conjuncture of the Geopolitical Codes: Lithuania's Foreign Policy in the Region}

Lithuania cannot act successfully alone either globally or regionally, since it has not enough natural and human resources. Lithuania should combine its efforts with another one or several countries in order to enhance its own structural power. Taking the role of formative subject and making an geopolitical alliances by cooperating with the states having the similar political visions and interests is the most effective way to avoid the manipulations of great geopolitical powers (or amortise them at least).

Making alliances with certain states would be meaningful if the power of union or alliance were significant enough to provide possibilities of the protection of national interests and influence actively the external environment in higher level.

The importance of the regional security projects ("self-made" regional geopolitical alliances instead of being constructed by external actors) would become especially important to Lithuania, in case Russia tries to transform Central and Eastern Europe into the arena of its geopolitical combinations by using the aim of the US and the main continental states of the EU to limit the power of each other.

The question is what kind of regional alliance is optimal to Lithuania in order to amortise the negative influence on national security of the global geopolitical changes. Lithuania had two ways of getting closer to the Western security structures in the beginning of the Euroatlantic integration in the last decade of 20th century. The alliance with Poland was the first way and the orientation to Nordic countries was the second one. Today Lithuania faces the similar dilemma.

Lithuania would expect becoming the geopolitical link between the region of Central and Eastern Europe and North Europe by making an alliance with several Nordic countries. This choice would raise the possibilities of Lithuania to integrate into the economic core of the EU, but it would also increase its dependence on the foreign policy of the Nordic states. Nordic countries regard the questions of the security of the Baltic States only in frames of the common policy towards Russia. On the other hand, Russia meets the projects of co-operation among the Baltic and Nordic states fairly approvingly, because this formations remain open for its influence. Therefore, the orientation of Lithuania towards the geopolitical space of the Nordic countries would create the favourable conditions for the geopolitical manoeuvres of Russia, which could turn back the country to the "grey zone" of security. The tendency of the Nordic countries towards neutrality do not presuppose the active role of these states in the dimension of "hard power" and do not coincide with Lithuania's geostrategic interest to counter-weight or weaken the spread of the geopolitical power of Russia in the Baltic States.

Poland is the largest and most structurally powerful country in Central Europe and is attracting the attention of all the three main geopolitical actors because of its geopolitical situation. The transformation of the interrelations of the EU and Russia is impossible without including Poland in their geopolitical schemes. Also the transformation of the relations of the US and Russia or the US and the EU is impossible 
without inclusion of Poland in some cases ${ }^{118}$. The structural power of Poland allows it to pursue an active foreign policy in all Central and Eastern Europe and influence the geopolitical behaviour of the more powerful states.

Lithuania should develop further the strategic partnership with Poland and strive for the formation of the geopolitical alliance. This could neutralise the main vulnerabilities of Lithuania, which would remain in the case of the orientation towards geopolitical space of Nordic countries. The geostrategic interests of Poland and Lithuania (especially towards the US and Russia) coincide in fact contrary to the interests of Lithuania and Nordic countries. The alliance between Poland and Lithuania would strengthen the positions of the later exactly in the sector of "hard" power and, therefore, it is so important.

Lithuania could implement its interests more effectively in all levels in the frames of its strategic partnership with Poland for the following reasons:

- close relations with the US would be guaranteed via Poland

- Poland may become the advocate of Lithuania's interests inside the EU

- it would let to implement active common politics of them both towards the Kaliningrad region, Byelorussia and the Ukraine instead of rivalry one

- it would be easier to identify and neutralise some threats coming from Russia by acting together

- Lithuania could join its system of power with the West European one only by wiring the electric power bridge through Poland and so reduce its energetic dependence on Russia. Therefore Poland is very important to Lithuania in energy sector ${ }^{119}$.

Poland should be interested in the strategic partnership with Lithuania for the following reasons:

- Lithuania could become an effective geopolitical link between Poland, Latvia and Estonia and eventually the Nordic countries as well, i.e. it could become the channel of the power spread of Poland towards North

- it would be better to act together with Lithuania or through it as the mediator in the relations with Byelorussia and Ukraine, because of the caution towards Poland rooted historically in the post-Soviet states in Eastern Europe

Co-operation through co-ordination of actions without identifying with it or "dissolving" itself in the Polish sphere of influence should be the principal Lithuania's policy towards Poland approaching the proposed partnership through the prism of political autonomy. Lithuania could match the structural power that of Poland by performing specific geopolitical functions in some spheres (e.g. in the relations with Byelorussia and the Ukraine) so influencing the geopolitical behaviour of Poland in desired direction.

Lithuanian-Polish geopolitical alliance could perform the function of moderator between the EU and the US successfully by co-ordinating the politics of both of them towards Eastern Europe and informing them about the geopolitical manipulations of Russia in case rivalry between them on the global level. So Lithuania would strengthen its position that of "expert on the East" and the Polish-Lithuanian axis

\footnotetext{
${ }^{118}$ Laurinavičius Č., Motieka E., Statkus N., (note 7) p. 308.

119 Ibidem, p. 252.
} 
might become the main co-ordinator of the EU policy towards the East. This program of action co-ordinated with Poland would enhance the relevancy of Lithuania in both the US and the EU geostrategic plans, which means the better guarantees of security as well.

Lithuania would achieve the possibility to implement successfully its local and regional geopolitical interests, i.e. forming the mechanisms of the "inclusion" of Kaliningrad into the EU, turning Byelorussia into the barrier to the spread of Russian influence and intensifying the relations between the EU and the Ukraine in case the geopolitical Lithuanian-Polish alliance attracted the attention of the great geopolitical powers (the US and the main European continental states) and were able coordinate the politics of the great Western states towards Eastern Europe (Russia, Byelorussia and the Ukraine).

If Lithuania were able to implement these tasks even partly in the short-term or mid-term period we could state that it is capable to influence the external environment and, therefore, the conditions for the regional leadership of Lithuania had emerged.

However, if due to unfavourable regional and local political situation Lithuania will be unable to pursue its goal of furthering Lithuanian-Polish geopolitical alliance, alternative geostrategic projects should be developed. 